\title{
Compositional observations for Islamic Glass from Sīrāf, Iran, in the Corning Museum of Glass Collection
}

\author{
Carolyn M. Swan ${ }^{\text {a }}$, Thilo Rehren ${ }^{\text {b }}$, James Lankton ${ }^{\text {c }}$, Bernard Gratuze ${ }^{\text {d }}$, and Robert \\ H. Brill e \\ ${ }^{a}$ UCL Qatar, Doha, Qatar \\ ${ }^{\mathrm{b}}$ College of Humanities and Social Sciences, Hamad bin Khalifa University, Doha, Qatar, \\ and UCL Institute of Archaeology \\ ${ }^{\mathrm{c}}$ UCL Qatar, Doha, Qatar \\ d Institut de Recherche sur les ArchéoMATériaux (IRAMAT), Centre National de la \\ Recherche Scientifique (CNRS), and Université d'Orléans, Orléans, France \\ ${ }^{\mathrm{e}}$ Corning Museum of Glass, Corning, NY \\ *Corresponding author: Carolyn Swan (email: c.swan@ucl.ac.uk or carrie.swan@gmail.com; \\ Tel. +974 4000 2817)
}

\begin{abstract}
The medieval port city of Sirāf (ca. 800-1050 CE) on the north coast of the Persian/Arabian Gulf linked the core lands of the 'Abbāsid caliphate with India, China, Africa, and beyond. 101 glass fragments recovered from the 1966-1973 excavations at Sīrāf and now at the Corning Museum of Glass were analysed using LA-ICPMS in order to explore the glassmaking raw materials and technology of the objects found within the city, as well as to address issues of the production and trade of glass during the Islamic period. The results indicate that the main groups of glass at Sirnaff likely date to the $9^{\text {th }}$-early $11^{\text {th }}$ centuries and can be subdivided by the trace elements zirconium and chromium. Chemical matches with some likely Indian glass, and with glass finds from South and Southeast Asia, underline the pivotal role of the Gulf in the eastward movement of Islamic glass via the Indian Ocean trade network, as well as the influx of Indian glass into the Islamic world. Glass bangles and a small number of vessel fragments likely date to the late $11^{\text {th }}$ century or later, and their chemical compositions indicate different production origins.
\end{abstract}

\section{Keywords}

Sīrāf, Siraf; Iran; Gulf; Islamic glass; bangles; Indian Ocean trade; LA-ICPMS; zirconium; chromium; manganese; high alumina

\section{Highlights}

- $90 \%$ are plant-ash glasses from $9^{\text {th }}$-early $11^{\text {th }}$ centuries, with subgroups based on zirconium and chromium 
- Glass debris and chunks chemically match the majority of the glass at Sīrāf, indicative of local working

- Locally-worked types chemically match glass fragments found in Sri Lanka and Thailand, indicating export of Islamic glass

- A small number of fragments are high-alumina glass, likely imports from South Asia

- Bangles are chronologically and chemically distinctive, with low manganese and high soda

- Low-manganese glasses may be chronologically and technologically indicative

\section{Introduction}

Sinrāf is one of the largest archaeological sites on the coast of Iran. Archaeological and literary sources agree that the city was a very wealthy port during the early medieval era, ca. 800$1050 \mathrm{CE}$. It served as an active commercial hub involved in the movement of goods between the 'Abbāsid lands of Iraq and Iran and the wider world of the Indian Ocean trading network: India, Southeast Asia, China, East Africa, and the Red Sea. Sīrāf occupied a strategic position on the northeastern coast of the Persian/Arabian Gulf, being located approximately halfway between the rivers of Mesopotamia and the Strait of Hormuz leading to the Indian Ocean (Figure 1). Medieval geographers comment that Sīrāf was an extremely prosperous port during the $9^{\text {th }}-10^{\text {th }}$ centuries: according to the mid- $10^{\text {th }}$ century writer Iștakhrī, Sīräfi merchants amassed huge fortunes and lived in sumptuous multi-storeyed houses paid for by the trade of luxury goods including pearls, gems, ivory, ebony, and spices (Whitehouse 1968: 3; Whitehouse 1970: 142).

Seven seasons of archaeological excavation took place at Sīrāf from 1966 to 1973, conducted by the British Institute of Persian Studies under the direction of David Whitehouse. Research findings related to the archaeology of the site have been published in a series of interim reports (Whitehouse 1968, 1969, 1970, 1971, 1972, and 1974), in monographs on the major areas of excavation (Whitehouse 1980, Whitehouse 2009) and some of the material evidence (e.g. Lowick 1984, Tampoe 1989, Khakzad et al. 2015, Wood and Priestman 2016), as well as in a conference proceedings (Tabadar and Mashayekhi 2005). The glass artefacts and other finds excavated at Sīrāf are currently stored in the British Museum, and a study of this material has reportedly been underway since 2007.

The Corning Museum of Glass in Corning, New York, has just over 100 fragments of glass from Sīrāf that were at one time in the personal research collections of Robert Brill and David Whitehouse. This paper presents an exploratory examination of the Sīrāf glass in the Corning Museum of Glass by LA-ICPMS in order to expand the corpus of data available for Islamic glass in general, but more specifically to investigate and characterize the types of glass used at Sīrâf in light of the city's economic and geographic significance during the early Islamic period (ca. $9^{\text {th }}-11^{\text {th }}$ centuries CE). 


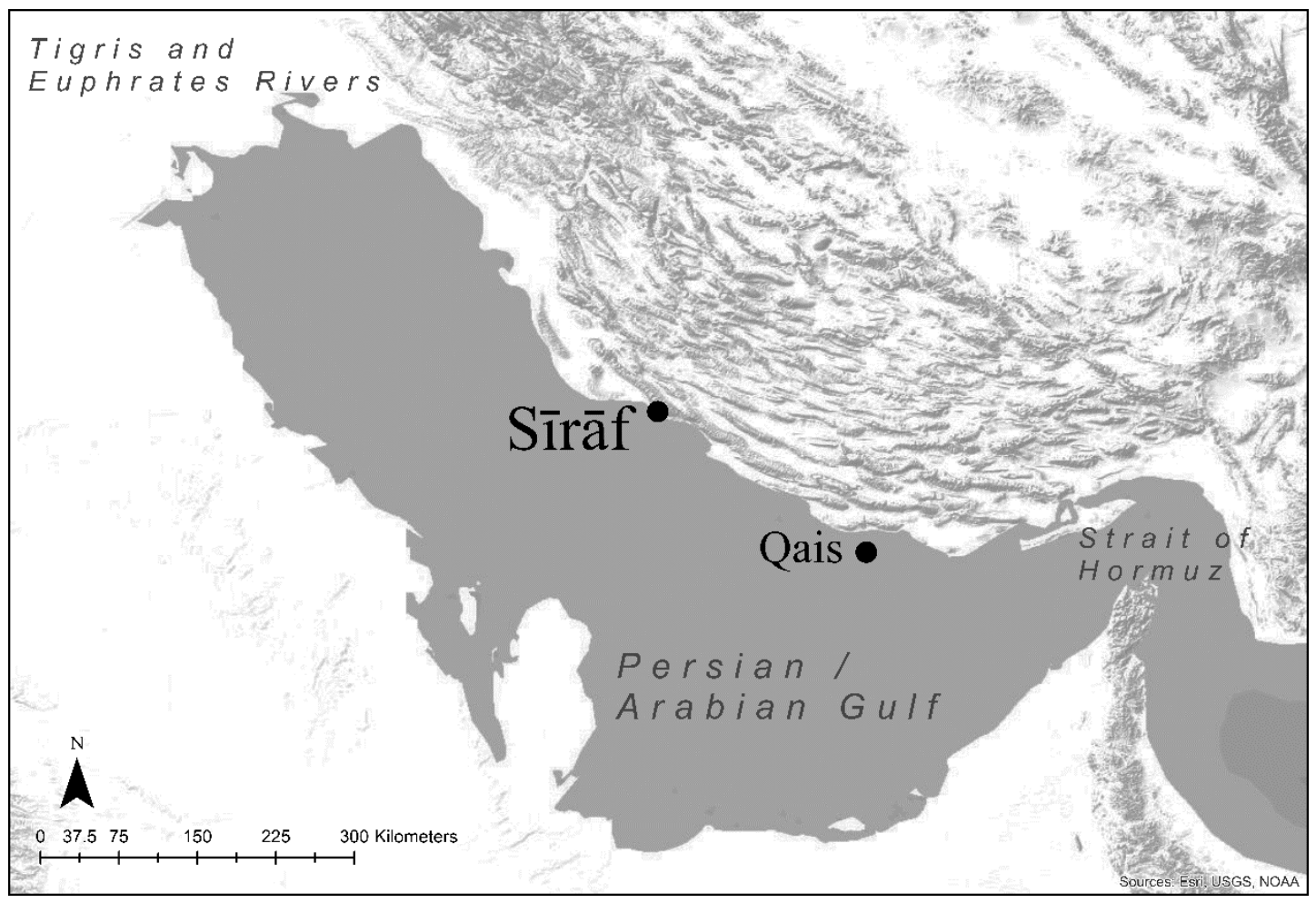

Figure 1: Map of the Persian/Arabian Gulf indicating the location of Sìräf. (Map: C. Swan)

\subsection{The site of Sìrāf}

The archaeological remains of medieval Sīrāf (modern Taheri) stretch approximately $2.5 \mathrm{~km}$ along a shallow, south-facing bay bounded closely on the north by parallel sandstone ridges. The western half of the site received the most attention during excavation: domestic structures, mosques, warehouses, shops, aqueducts, city walls and gates, and an industrial quarter dating to the early Islamic period were identified; in addition to these discoveries, an earlier Sasanian fort and later ca. 15 ${ }^{\text {th }}$-century houses, mosques, and shrines were also identified (for a concise summary of the urban landscape and occupational chronology, see Mason and Keall 1991: 55-57).

There appear to be three general phases of occupation at the site: a fort during the Sasanian period $\left(8^{\text {th }}\right.$ century or earlier), the wealthy urban port of Sīrāf during the Islamic period $\left(9^{\text {th }}\right.$ $11^{\text {th }} / 12^{\text {th }}$ centuries), and a small, non-urban settlement called Shilau during the early modern period $\left(15^{\text {th }}-16^{\text {th }}\right.$ centuries). The era of greatest prosperity was decidedly the $9^{\text {th }}-10^{\text {th }}$ century, when the urban area expanded to its greatest extent and the port served as a hub for trade and economic activity, involving active production as well as the import of goods from distant lands. The city began to decline in the late $10^{\text {th }}-11^{\text {th }}$ centuries in part due to a severe earthquake in $977 \mathrm{CE}$, the fall of the Būyid dynasty ca. $1055 \mathrm{CE}$, and the subsequent rise of Qais as an alternate hub for trade. Decline seems to have accelerated in the $12^{\text {th }}$ century, and by the early $13^{\text {th }}$ century the writer Yâqūt comments on the poverty of the nearly-deserted city, but the archaeology indicates some limited settlement activity continuing into the early modern era. 
Although ambiguous, there is some archaeological evidence for the possible production of glass or glass objects in or around Sīrāf during the $9^{\text {th }}-12^{\text {th }}$ centuries. According to the excavator, a "group of kilns" was discovered in the western suburb near the shore, at Site D. This large industrial area dating to the $9^{\text {th }}-10^{\text {th }}$ centuries was certainly devoted to the production of ceramics, while one kiln and a small rubbish pit contained many fragmentary glass vessels as well as large quantities of glassworking debris including drops, trails, and glass slag (Whitehouse 1968: 5, 12-14). Excavators at the time noted that this glass waste all belonged to the type of glass that was most common at Sirāf, which "suggests that glass, too, was manufactured here" (Whitehouse 1968: 14). However, no conclusive evidence for the production of glass at Site D was ever identified, and it was later suggested that the glassy materials may instead represent material that was brought to the site for the local glazing activities of the potters (Whitehouse 1971: 15; Mason and Keall 1991). In a 1973 survey of the territory surrounding Sīrāf, a joint venture made with the Iranian Centre for Archaeological Research, a ca. $9^{\text {th }}-12^{\text {th }}$ century glass factory was identified in the Jamm Valley $16 \mathrm{~km}$ to the north at Bid-i Kahr; just south of a large mound (called Tul-i Shisheh, "mound of glass") was a $100 \mathrm{~m}^{2}$ area covered with glass slag and debris (Whitcomb, in Whitehouse 2009: 83; see also Whitehouse 1968: 19), but it does not appear that this site was ever explored through controlled excavation.

\subsection{The glass of Sīrāf}

No typological study of the glass was evidently made by Whitehouse or his team, and the only published information about the glass artefacts from Sīrāf is a general overview included in the first excavation season's interim report (Whitehouse 1968: 18-20). During the 1966 excavations, glass was noted as being second only to pottery in terms of artefact abundance, with more than 1000 glass fragments recovered in the first field season alone (Whitehouse 1968: 18). The majority of the glass was said to come from securely stratified contexts dating to the $9^{\text {th }}-10^{\text {th }}$ centuries CE, the period of greatest prosperity for Sīrāf (Whitehouse 1968: 18).

Glass fragments were recovered from all areas of excavation, and according to visual examinations by Whitehouse the finds fell into three broad categories: "local glass," "glass of east Persian type," and "Egyptian glass" (Whitehouse 1968: 18-19). Whitehouse described the local glass as blue and green glass vessels with thinly blown walls: "the green glass, which comprises 90 per cent of this material, has a bubbly metal, sometimes with a distinct yellowish tint," and the remaining 10\% was described as a blue glass that "is bubble-free with a uniform light cobalt tint" (Whitehouse 1968: 18). Whitehouse noted that local glass was rare in Period 1 (ca. 800 to 825-850) but was the dominant type at the site during Period 2 (ca. 825-850 to 977-1055); he records that the local glass vessel types include blown bowls, beakers, goblets, bottles, lamps, sprinklers, and alembics, and that decoration was not common, with just a few fragments being cut or mould-blown. Whitehouse described the "east Persian" type as a high-quality colourless glass, often adorned with cut or carved decoration; most of the vessels of this type are beakers, bottles, and flasks, and were thought by Whitehouse to bear "a family likeness" to some of the glasses of Nīshāpur (1968: 19). Whitehouse went on to note that glass of "Egyptian origin" is rare at the site (with a total of just 10-20 pieces identified in the first season of excavations) and consists of vessels with 
mould-blown and carved decoration, although he does not explain how exactly the "Egyptian origin" glass can be differentiated from the other two types.

Two additional types of glass were reported to emerge in later, post-10 $0^{\text {th }}$ century, deposits at Sīrāf (Whitehouse 1968: 19). Whitehouse noted that bangles begin to appear in Period 3 (late $11^{\text {th }}$ century and onwards). These bangles are plain or decorated with wound threads of blue, green, red, or yellow glass. Vessels described as having a blue-green fabric also appear in later deposits, and this type of glass was thought to be similar to the fragments found at the factory site at Bid-i Khar (Whitehouse 1968: 19).

\section{Materials and Methods}

Approximately three-quarters of the Sīrāf glass fragments now in the Corning Museum of Glass were collected by Robert Brill during visits to the excavations in the late 1960s, and the remainder come from the personal collection of David Whitehouse. Nine of the fragments (siraf_001-009) that were collected at the site by Paul N. Perrot and Robert Brill in 1967 and published in the 1990s (Brill 1999a and 1999b) have been re-analysed in this current study.

In terms of object types, the nine fragments re-analysed here were described in previous publications as cullet, vessel fragments, or waste glass dating to the $9^{\text {th }}-10^{\text {th }}$ centuries (Brill 1999a: 88, VII E; Brill 1999b: 173). For the majority of the fragments in the Corning Museum of Glass collection, no detailed typological attribution has been made beyond "vessel" and "working debris" or possible "chunk". From photographs of the fragments, the individual vessel parts can be identified (e.g. base, rim, handle), although the exact form or type of the vessels cannot be determined: in Figure 2, at the left are examples of working debris and at the centre are examples of vessel bases, rims, and body fragments; at the right is siraf_009, the only fragment with a clearly identifiable form, a small blue bottle with a cylindrical neck that was a widespread type in the Early Islamic period with parallels, for example, at Nīshāpur (Kröger 1995: 74-75). Bangle fragments and one "kohl stick" (a thin rod likely used for the application of cosmetics) are easily identified (Figure 3).

Excavation context is known for only 20 fragments in the collection (see Supplemental Table). Two objects (siraf_089 and_101) derive from the initial sounding, designated Site A. Six objects (siraf_093-098) were recovered from the area of the congregational mosque at Site B, four of which are surface finds (siraf_093-096). One object (siraf_090) comes from residential building $\mathrm{N}$ at Site E, dated to the $14^{\text {th }}-15^{\text {th }}$ centuries. Nine objects (siraf_075-081 and 099-100) come from residential buildings at Site F, dated to the $9^{\text {th }}-11^{\text {th }}$ centuries but thereafter used as a refuse dump (Whitehouse 1969: 53), including two stratified finds from houses E (siraf_099) and R (siraf_100) and surface finds from house S (siraf_075-081). There is no information about the archaeological context of the remaining glass fragments (siraf_001-074, 082-088, and 091) and most, if not all, are likely to have been surface finds. Without contextual information, the date of the Corning fragments should broadly be taken as ca. $9^{\text {th }}$-early $11^{\text {th }}$ or $12^{\text {th }}$ centuries CE, the main period of occupation at Sīrāf, although the bangles can be dated more securely to the late- $11^{\text {th }}$ century or later as Whitehouse clearly notes that bangles first appear in Period 3 contexts (1968: 19), while the kohl stick likely dates to $14^{\text {th }}$ - to $15^{\text {th }}$-century Sīrāf (Shilau). 

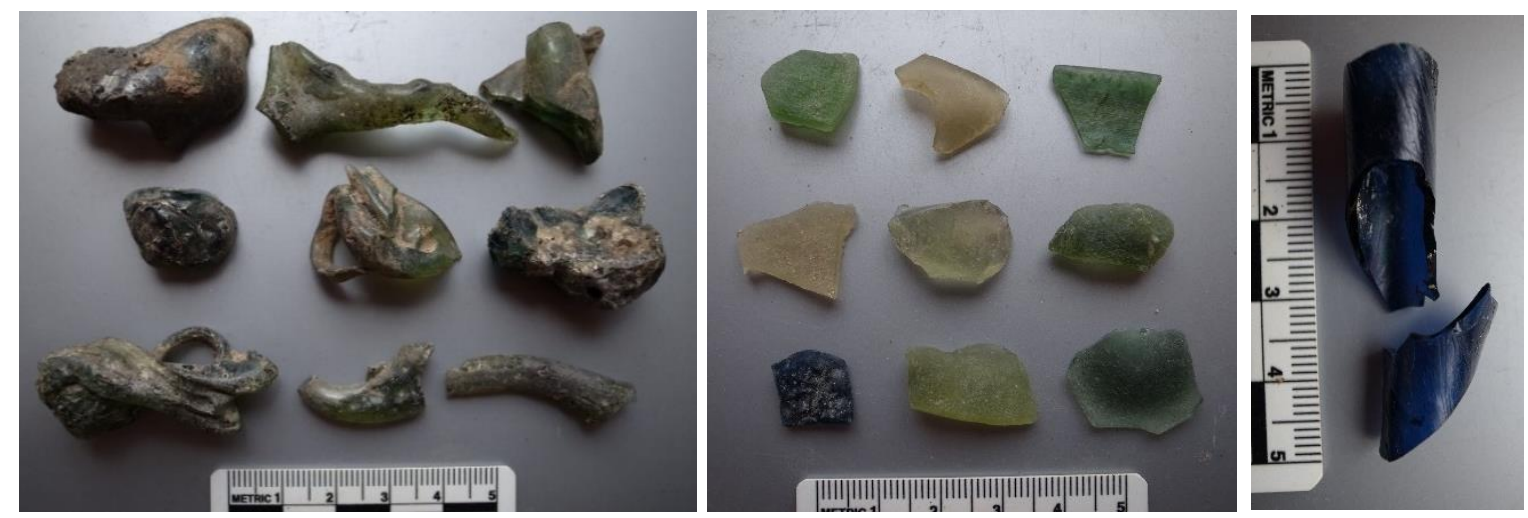

Figure 2: Examples of glass objects from Sìräf within the Corning Museum of Glass collection: on the left are samples siraf_010-018 (reading left to right, top to bottom); in the centre are samples siraf_045-053 (reading left to right, top to bottom); on the right is sample siraf_009, the cylindrical neck of a small blue bottle. (Photos: J. Lankton)
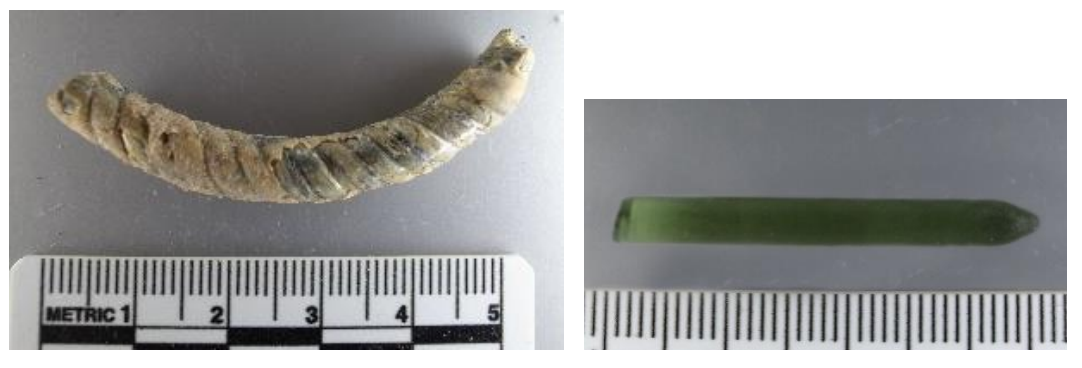

Figure 3: Example of a glass bangle (siraf_095, at the left) and the kohl stick (siraf_090, at the right) from Sìräf in the Corning Museum of Glass collection. (Photos: J. Lankton)

The analyses were conducted in 2015-2016 by James Lankton and Bernard Gratuze at the Institut de Recherche sur les ArchéoMATériaux (IRAMAT) in Orléans, France, using Laser Ablation Inductively-Coupled Plasma Mass Spectrometry (LA-ICPMS). The ablation system used consists of a Resonetics M50E excimer laser working at $193 \mathrm{~nm}$ coupled with a Thermo Fisher Scientific ELEMENT XR mass spectrometer. This mass spectrometer offers the advantage of being equipped with a three-stage detector: a dual mode (counting and analogue modes) secondary electron multiplier (SEM) with a linear dynamic range of over nine orders of magnitude, associated with a single Faraday collector which allows an increase of the linear dynamic range by an additional three orders of magnitude. This feature is particularly important for laser ablation analysis, as dilution of the sample is impossible compared to ICPMS with liquid sample introduction. For glass, it is therefore possible to analyse major, minor, and trace elements in a single run regardless of their concentrations and their isotopic abundance.

The excimer laser was operated between 4.5-5.5 mJ with a repetition rate of 6-10 Hz. The beam diameter was adjusted between 60 and $100 \mu \mathrm{m}$ according to the composition of the glass, to avoid saturation from particular elements such as manganese, copper, tin, or lead. A pre-ablation time of 20 seconds was set in order to eliminate the corrosion layer and the transient part of the signal, which is then acquired for 25-50 seconds corresponding to 10-20 mass scans from lithium to uranium (the signal in counts/second is measured in low resolution mode for 58 different isotopes). Three ablations are carried out for each sample, 
and the final calculated composition is the average of the composition calculated for each analytical spot. Calibration was performed using five reference standards (NIST610; Corning Reference Glasses B, C, and D) as well as an in-house standard glass (APL1) with composition determined by Fast Neutron Activation Analysis that is used for chlorine quantification; these standards were run periodically to correct for potential drift (Gratuze 2013 and 2016). The standards are used to calculate the response coefficient $(\mathrm{k})$ of each element (Gratuze 2016). The calculated values are normalised against ${ }^{28} \mathrm{Si}$, the internal standard, to produce a final percentage.

The detection limits of this analytical setup range from 0.1 to $0.01 \%$ for major elements and from less than 1 to $500 \mathrm{ppm}$ for the other elements, depending largely on background count levels. In order to validate the obtained concentration results, glass reference standards Corning A and NIST 612 were regularly analysed as unknown samples throughout the analytical sequence. The average values obtained during the analysis for these glasses usually agree within 5-10\% with the published (Corning A) and certified (NIST 612) values. These values, as well as those calculated on Corning B (although this reference glass is used to calculate the calibration coefficients), are also used to monitor the consistency of analytical data collected during different analytical sessions.

The purpose of choosing LA-ICPMS analysis for this collection of material is to explore the chemical characteristics and range of glass types present at Sīrāf in order to offer general insight into Islamic glass of this region and era, which is currently less studied than glass from other regions and periods (Swan forthcoming). The second goal is to determine whether the three general categories that were visually observed by Whitehouse during excavation (i.e. "local glass," "east Persian" glass, and "Egyptian origin" glass) might be confirmed or further distinguished using chemical analysis, and by comparing this with chemical data for glass from contemporaneous sites around the Islamic world; a closely related objective is to see whether the bangles are distinctive in any way from the other glasses.

\section{Results}

The data shown in Table 1 and discussed below are for 102 glass samples taken from 101 different archaeological objects: 92 fragments of vessels or related debris, eight fragments of bangles, and one fragment of a kohl stick. Analyses were initially conducted for 107 objects, but the data for two fragments were discarded entirely due to the extreme weathering of the glass, which had clear reductions in the soda content (ranging 0.4-1 wt $\% \mathrm{Na}_{2} \mathrm{O}$ ) and other observable chemical alterations; one fragment was additionally discarded as it proved to be pure quartz, consisting of $99.6 \mathrm{wt} \%$ silica - this object was collected by Brill alongside the glass fragments, and could be quartz raw material related to the purported glass production taking place at Sīrāf or then again a fragment of rock crystal. Analyses made on two bangle fragments show that they come from the same object, thus an average of the data is considered here (siraf_095); four vessel fragments were found to come from two objects, so an average of the data is again used in these cases (siraf_004 and siraf_098).Two samples were taken from a polychrome bangle, one sample from the blue glass core (siraf_093_b) and one from the yellow glass thread decoration (siraf_093_y). 


\subsection{General chemical observations}

The 101 analysed samples from Sīrāf are all of the soda-lime-silica $\left(\mathrm{Na}_{2} \mathrm{O}-\mathrm{CaO}-\mathrm{SiO}_{2}\right)$ glass type. All but three of the glasses have potash and magnesia levels between 1.7-3.9 wt $\% \mathrm{~K}_{2} \mathrm{O}$ and 1.7-5.1 wt $\% \mathrm{MgO}$, consistent with the use of a vegetable soda source as a flux, e.g. halophytic plant ash (Freestone 2006). For the plant ash soda glasses at Sīrāf, the trace elements zirconium and chromium are found to be the most effective discriminators (Figure 4), and two broad groups can be described: the Main Group constitutes almost $65 \%$ of all samples analysed, with an average zirconium content near $400 \mathrm{ppm} \mathrm{Zr}$; distinctive from this Main Group, some 25\% of the samples form the comparatively Low Zirconium group, averaging near $70 \mathrm{ppm} \mathrm{Zr}$. The bangles reflect three chemical compositions that are different from the vast majority of the vessel glasses: six bangles are distinctive with high soda (17 wt $\%$ soda or more) and/or extremely low manganese (averaging $0.06 \mathrm{wt} \% \mathrm{MnO}$ ), one highsoda bangle has high alumina and other anomalies, and one bangle has even higher alumina. Five outlier fragments are of interest: one kohl stick fragment is a high alumina glass, and four vessel fragments have low manganese that may indicate their chronological or technological connection to the bangles. These different chemical types are described in more detail below.

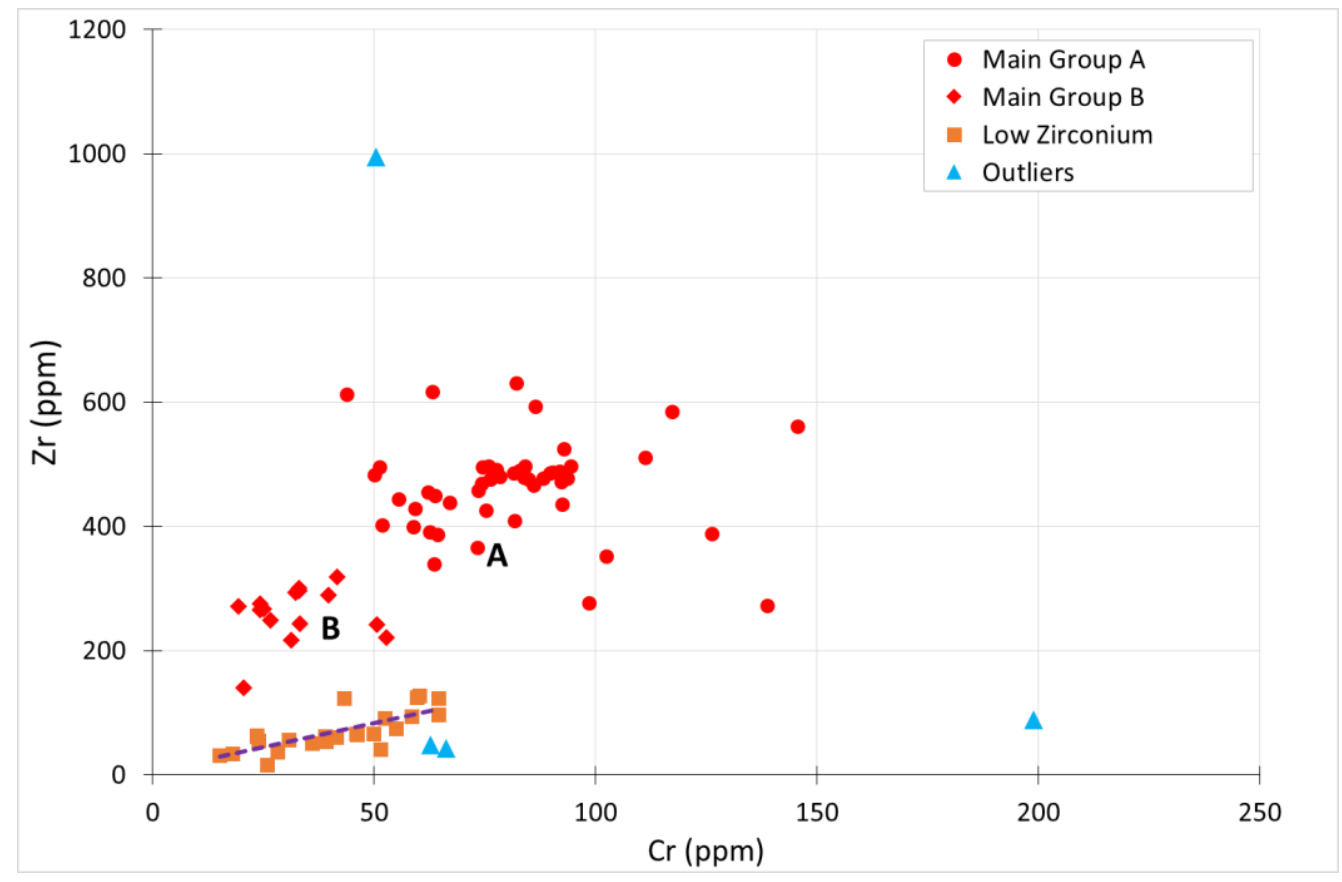

Figure 4: Scatterplot of Sìräf vessel glass showing zirconium vs chromium of the Main Group (with subsets $A$ and B), the Low Zirconium group, and the outliers (note: bangles and kohl stick are not shown).

\subsection{Main Group}

64 of the samples from Sīräf contain more than $150 \mathrm{ppm} \mathrm{Zr}$, and most have well over 250 ppm. The majority of these samples has elevated manganese, between 1 and $2.5 \mathrm{wt} \% \mathrm{MnO}$, although ten fragments have somewhat less than half that amount $(0.3-0.7 \mathrm{wt} \% \mathrm{MnO})$. A 
dozen of the glasses have elevated transition element levels typical of recycled glass (Jackson 1995). Two fragments in this group are intentionally coloured blue with over 500 ppm cobalt. One naturally-aqua vessel base (siraf_053) stands out with elevated barium (2300 ppm Ba) and the highest levels of phosphate, lanthanum, and tungsten.

There is a subtle, but observable, internal separation between the glasses of the Main Group according to their relative levels of zirconium and chromium (Figure 4). 49 samples (Main Group A) have more than $250 \mathrm{ppm} \mathrm{Zr}$ and more than $50 \mathrm{ppm} \mathrm{Cr}$, reaching up to about 600 ppm Zr and nearly 150 ppm Cr. 15 samples (Main Group B) have intermediate levels of zirconium not exceeding $320 \mathrm{ppm}$, and are consistently below $55 \mathrm{ppm}$ chromium; these samples also have lower aluminium, with half containing less than $1 \mathrm{wt} \% \mathrm{Al}_{2} \mathrm{O}_{3}$. This internal separation, based on the range of zirconium, is also apparent in associated elements such as hafnium, iron, and titanium; it likely represents a continuum of increasing amounts of trace elements rather than fundamentally distinct chemical groups. The samples seem to follow the same broad elemental correlations, and the different levels are probably a reflection of the different degree of minerals other than quartz in the silica source.

\subsection{Low Zirconium group}

24 samples contain less than $150 \mathrm{ppm} \mathrm{Zr}$, and they consistently have less than $70 \mathrm{ppm} \mathrm{Cr}$. Furthermore, in this group both elements appear more tightly correlated in their concentrations than among the Main Group samples (Figure 4). These samples have higher magnesia and alumina as well as lower lime than the glasses of the main group; they also contain much lower titanium and strontium but higher rubidium and barium. 11 samples show some evidence of recycling and 13 appear to be pristine glass, most of which is colourless; in fact, the majority of the colourless or nearly colourless glasses of the sample set are Low Zirconium glasses. Four of the Low Zirconium samples are coloured dark blue or black by cobalt and/or copper concentrations above 500 ppm Co and $4000 \mathrm{ppm} \mathrm{Cu}$; one of these has very high zinc as well. The Low Zirconium glasses do display some level of variation within the group: 19 of the samples have slightly higher alumina, averaging 2.5 $\mathrm{wt} \%$, compared to five samples with an average of $1.3 \mathrm{wt} \% \mathrm{Al}_{2} \mathrm{O}_{3}$. Slight differences also exist in the level of soda, titanium and other trace elements (e.g. the REEs), as well as in the manganese levels. The 19 samples have, with few exceptions, between 1 and $2 \mathrm{wt} \% \mathrm{MnO}$ (only one has $0.5 \mathrm{wt} \%$, although as a cobalt-blue glass this is an exception anyway) whereas the other five samples have 0.3 to $0.6 \mathrm{wt} \% \mathrm{MnO}$, regardless of whether they have recycling indicators.

\subsection{Outlier fragments}

The glasses described above include over $85 \%$ of the samples from Sīrāf; however, four vessel fragments and the single kohl stick fragment have chemical compositions that are rather distinctive, thus they are considered separately. Three vessel fragments (siraf_006, siraf_022, and siraf_035) have zirconium in line with the Low Zirconium glass group while siraf_086 has extremely high zirconium (995 ppm Zr). All these vessel outliers are distinctive due to their very low manganese $(0.04 \mathrm{wt} \% \mathrm{MnO})$, which is indicative of an impurity rather than intentional addition of this ingredient. These four low-manganese glasses also tend to 
have lower silica and higher soda than the assemblage average, and do not show indications for recycling. The kohl stick of light green glass (siraf_090) is the same high alumina glass type as bangle sample siraf_094, which is discussed below.

\subsection{Bangles}

The eight bangles have notably different glass compositions, with some of the lowest silica as well as highest soda and potash levels within the entire assemblage. Three samples (siraf_076, siraf_078, and siraf_093) have very high arsenic ranging 100-190 ppm As. The chromium levels for all the bangles are below $60 \mathrm{ppm} \mathrm{Cr}$; the zirconium levels vary, but most are in line with the Low Zirconium glasses with the exception of siraf_075, siraf_077, and siraf_095 (with 160, 590, and 900 ppm Zr respectively). The most noticeable characteristics of the bangles are their manganese and soda contents. The extremely low manganese ranges from $0.02-0.2 \mathrm{wt} \% \mathrm{MnO}$, with an average of $0.06 \mathrm{wt} \% \mathrm{MnO}$ compared to the $1.5 \mathrm{wt} \% \mathrm{MnO}$ average of the non-bangle glasses. Half of the bangle samples exceed $17 \mathrm{wt} \% \mathrm{Na}_{2} \mathrm{O}$, whereas the average soda content for the non-bangle glasses from Sīrāf is only $13.5 \mathrm{wt} \% \mathrm{Na}_{2} \mathrm{O}$.

Most ancient and medieval glasses contain 1-3 wt $\% \mathrm{Al}_{2} \mathrm{O}_{3}$ (e.g. Freestone 2006: 203, table 2; see also Dussubieux et al. 2010). Bangle siraf_075 contains $4.7 \mathrm{wt} \% \mathrm{Al}_{2} \mathrm{O}_{3}$, and the glass is further distinguished by low potash, magnesia, and lime $\left(0.76 \mathrm{wt} \% \mathrm{~K}_{2} \mathrm{O}, 1.5 \mathrm{wt} \% \mathrm{MgO}\right.$, and $2.8 \mathrm{wt} \% \mathrm{CaO}$ ) as well as massively higher uranium (26 ppm U). Bangle siraf_094 (and kohl stick siraf_090) represents a second variety of high alumina glass, which has an even higher level of alumina $\left(8.1 \mathrm{wt} \% \mathrm{Al}_{2} \mathrm{O}_{3}\right)$ as well as the highest potash content $\left(7.2-7.9 \mathrm{wt} \% \mathrm{~K}_{2} \mathrm{O}\right.$ ) and one of the lowest silica contents $\left(57-58 \mathrm{wt} \% \mathrm{SiO}_{2}\right)$ of any of the Sīrāf glasses. The two types of high-alumina glass bangles also differ from the majority of the glasses in terms of their trace elements and have higher rare earth elements than do the other glasses from Sīrāf, with two to four times the average amount of yttrium, lanthanum, cerium, praseodymium, neodymium, and samarium; this further underscores the distinctiveness of these particular glasses within the sample set.

All of the bangles are made from aqua to blue coloured glass, and the colouring chemistry attests to the use of different additives to produce this range of hues. Of the bangles shown in Figure 5, for example, two are coloured by the addition of more than $5000 \mathrm{ppm} \mathrm{Cu}$, although siraf_077 has relatively low iron and is light blue-turquoise in colour while siraf_075 has higher copper as well as higher iron that creates a dark aqua colour; the blue glass of siraf_076 is not coloured by copper, but instead by more than $200 \mathrm{ppm}$ Co. The polychrome bangle siraf_093 is composed of a blue glass core (siraf_093_b) twisted with an opaque yellow thread (siraf_093_y): the blue glass is coloured by iron and traces of cobalt (over 200 ppm Co), while the yellow glass is coloured by the addition of lead-tin oxide ( $6.14 \mathrm{wt} \% \mathrm{PbO}$ and $7.54 \mathrm{wt} \% \mathrm{SnO}$ ) (e.g. Heck et al 2003) and has high indium (220 ppm In). 


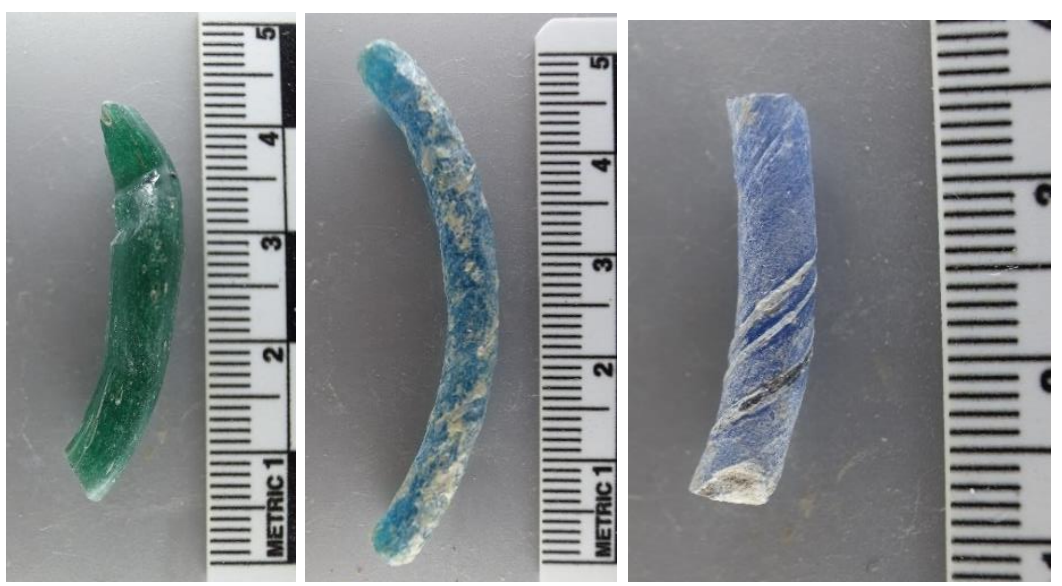

Figure 5: Bangles demonstrating the range of aqua to blue hues, and different colouring chemistry; left to right siraf_075, 077, and 076. (photos: J. Lankton)

\section{Discussion}

When considering Whitehouse's visual observations of the Sīrāf glass assemblage, it is possible to equate his "local" type with our Main Group and his "east Persian" type with our Low Zirconium glasses. Within our dataset, we do not see anything that might be indicative of the "Egyptian-origin" glass group that Whitehouse noted in his brief typological commentary, but this perhaps makes sense given the reported rarity of Egyptian glass at the site; with only 10-20 such objects recovered from the first season of excavation (Whitehouse 1968: 19), it would be unlikely that the Corning Museum's small collection of surface finds includes examples of this type.

The compositional data of the Main Group supports rather contradictory interpretations regarding the geochemical origins of this glass type, depending upon which compounds and elements are under consideration. While there are clear chemical similarities between this group and glasses from Syria-Palestinian or Levantine (i.e. Eastern Mediterranean) sites in terms of the major and minor compounds, we find that the Main Group has a fundamentally distinctive composition, in that its trace element signature - specifically its zirconium content - is unmatched by any data we know of from contemporaneous sites in that region, nor do the trace element patterns match any better with glasses from sites in Iraq and northern Iran.

\subsection{Main Group and Low Zirconium glasses}

The chemical composition of plant ash glasses is the result of a flux contributing potash, magnesia, lime, phosphate and other minor and trace oxides as well as soda (Barkoudah and Henderson 2006), while the silica source is either sand or crushed quartz that adds various amounts of impurities, including and beyond those oxides just mentioned (see also Rehren 2016). In the last decade or so, studies aiming to differentiate various plant ash glasses of Western Asia have observed broad compositional variations in major and minor elements (e.g. potash, magnesium, lime, and alumina) moving in an East-West direction across the region: plant ash glass from sites in Mesopotamia and Persia tends to have higher magnesia 
levels than does glass from sites in Syria-Palestine (Freestone 2006: 204-205, Figure 2; Simpson 2014: 204-206, Figure 20.4) as well as an overall higher magnesia-lime ratio (Freestone et al. 2017), while glasses in Iraq and Iran also tend to have amongst the lowest lime levels (Henderson et al. 2016: 138, Figure 3). When we plot the Sīrāf Main Group and Low Zirconium glasses using the same criteria in Figure 6a and Figure 6b, our two groups appear to fit these geographic patterns: we see that our Low Zirconium samples plot alongside eastern glasses from Iraq and Iran while our Main Group plots very well with glasses from Egypt and Syria-Palestine. This suggests that Whitehouse's "east Persian" type is indeed from Iraq or Iran, whereas the "local" glass is not local but rather was imported to the site from glassmaking regions to the west. However, we do not in fact believe that the Main Group derives from Egypt or Syria-Palestine, based upon trace element data that underline the unique geochemical characteristics of the raw materials (see below) as well as a full consideration of the archaeological evidence (section 4.2).

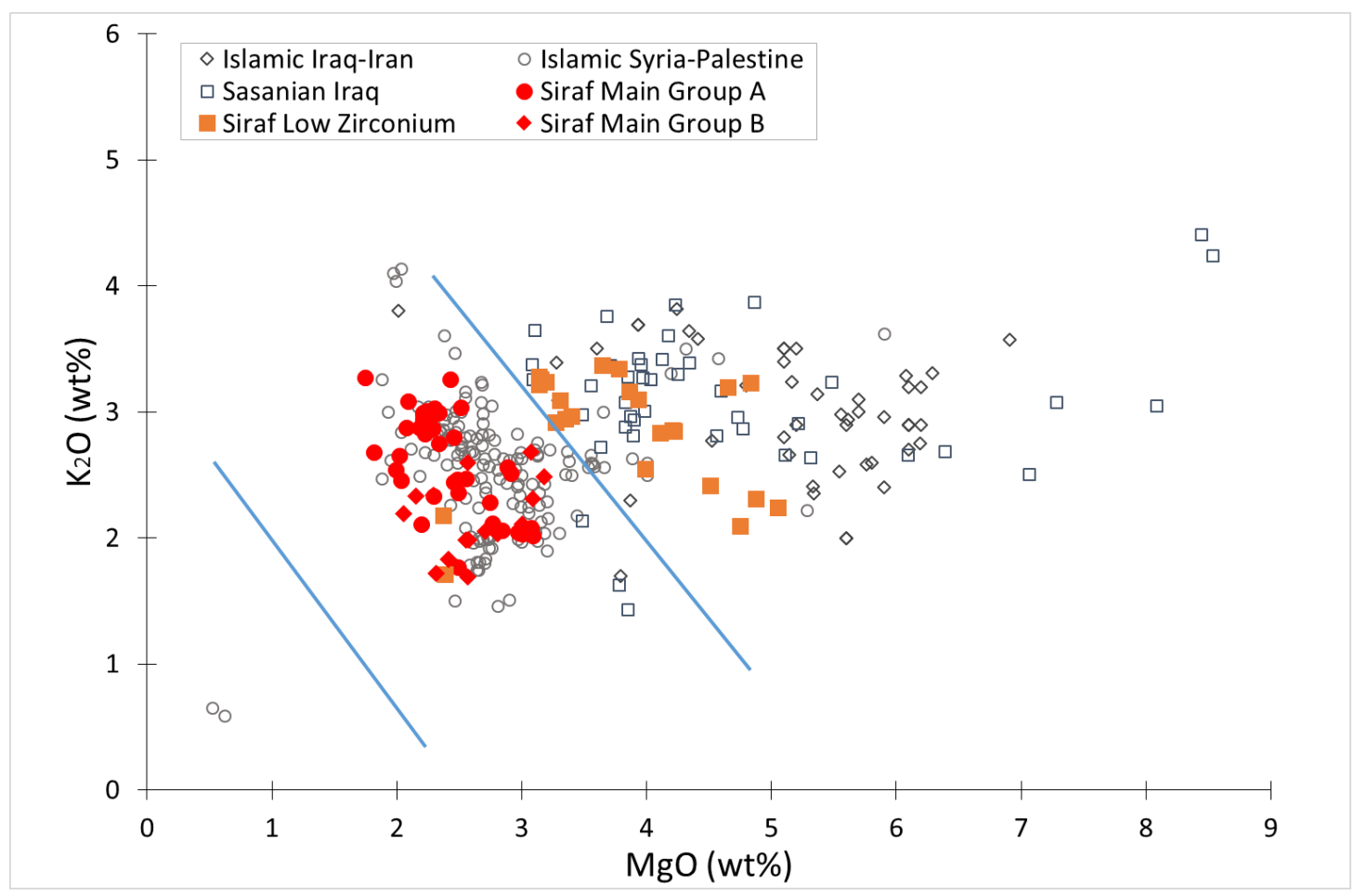




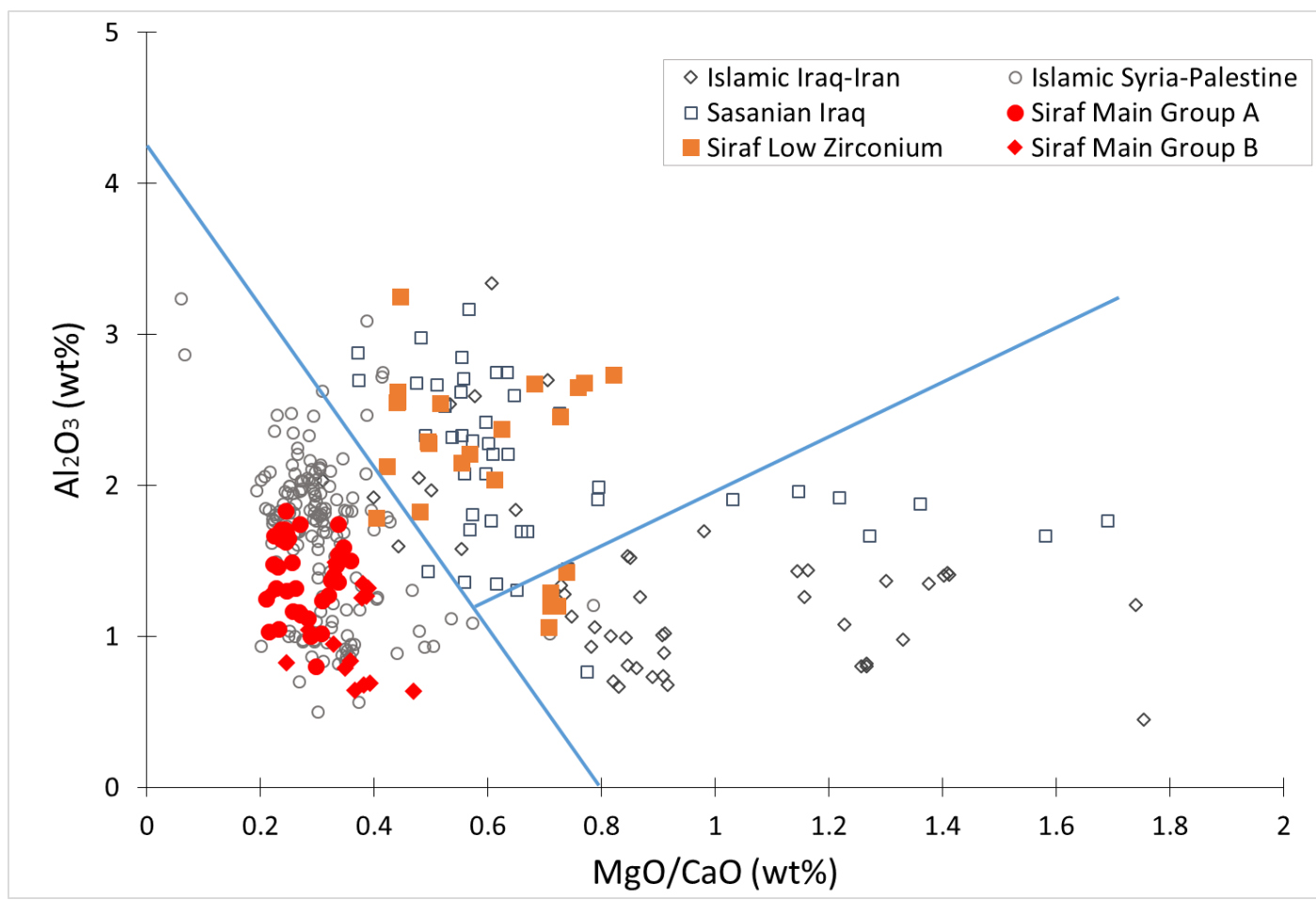

Figure 6a (top) and Figure 6b (bottom): Scatterplot showing (a) potash vs magnesia (b) and alumina vs magnesia/lime for the Sìräf vessel glasses (not including bangles or kohl stick), compared to published data of Islamic glass from Syria-Palestine (the sites of Banias in Israel, Tyre in Lebanon, and the Serçe Limanı shipwreck; data from Freestone et al. 2000, Freestone 2002, and Brill 2009, and see also Brill 2009 for discussion of the likely origins of the glass on board the Serçe Limanı ship. The sites of Beirut, Damascus, Khirbat al-Minyā, and Cairo; data from Henderson et al. 2017), Sasanian glass from Iraq (site of Veh Ardaširr; data from Mirti et al. 2009), and Islamic glass from Iraq and northern Iran (sites of Ctesiphon, Sāmarrā', and Nīshāpur; data from Henderson et al. 2016). Scatterplot (a) is prepared after Freestone 2006 and Simpson 2014, and scatterplot (b) is prepared after Freestone et al. 2017.

Compositional variation in certain trace elements (particularly those that are refractory and non-volatile) has shown great promise to discriminate regional plant ash soda glasses based upon the geological variation of the raw materials (Shortland et al. 2007). While soda-limesilicates can be very similar in terms of their major and minor elements, Shortland et al. (2007) successfully used trace elements titanium (Ti), zirconium ( $\mathrm{Zr}$ ), lanthanum (La), and chromium $(\mathrm{Cr})$ to differentiate Egyptian vs. Mesopotamian Late Bronze Age glasses, and Mirti et al. (2009) have used cerium (Ce) and zirconium ( $\mathrm{Zr}$ ) to define compositional groups within their sample set of Sasanian glasses. Most recently, Henderson et al. (2016) have successfully used trace elements that reflect relative impurity levels in glassmaking sands (specifically $\mathrm{Cr}, \mathrm{Fe}, \mathrm{La}, \mathrm{Zr}$, and $\mathrm{Ti}$ ) to distinguish regional production zones in the Levant, northern Syria, and Iraq/Iran; moreover, such analysis is shown to effectively discriminate chronologically-different glasses that were likely produced in the same region (e.g. the chromium content of Sasanian vs. Islamic glasses in Iraq and Iran). The separation of our Sirāf samples into the Main Group and the Low Zirconium glasses is based primarily on $\mathrm{Zr}$ and $\mathrm{Cr}$ (Figure 4), elements typically associated with the silica source. As noted previously, 
the Main Group averages $400 \mathrm{ppm} \mathrm{Zr}$ and has up to nearly $150 \mathrm{ppm} \mathrm{Cr}$ while the Low Zirconium group averages $70 \mathrm{ppm} \mathrm{Zr}$ and contains less than $70 \mathrm{ppm} \mathrm{Cr}$. A review of trace element data for broadly-contemporaneous plant ash glasses from sites in Western Asia (data from Henderson et al. 2016; our own unpublished data from Fusțāt in Egypt and Qașr al-Hayr East in Syria; unpublished data from sites in Palestine, Phelps pers. comm.) indicates that such glasses typically have only small to moderate levels of zirconium - most samples containing well below the level of 200 ppm Zr. The chromium levels of the Sīräf Main Group are clearly higher than the glasses from Egypt, Palestine, and southern Syria analysed by Henderson et al. 2016 (Figure 7a), but the Main Group A glasses are also quite distinctive from glasses from Iraq and northern Iran analysed in the same study; moreover, samples in the Sīrāf Main Group have notably higher $\mathrm{Cr} / \mathrm{La}$ ratios and 1000Zr/Ti ratios than glasses from either of these regions (Figure 7b). The Sasanian 1a group of Mirti et al. (2008, 2009) averages around $220 \mathrm{ppm} \mathrm{Zr}$ and $100 \mathrm{ppm} \mathrm{Cr}$; although on the higher end of the data range, the zirconium level of these Sasanian glasses is still much lower than that of the Sirrāf Main Group A glasses (Figure 7c), while the high strontium content of Main Group A with an average of around $730 \mathrm{ppm}$ is also remarkable and distinctive (Table 1).

One possible way to resolve the apparent discrepancy between a 'Syria-Palestine' flux signature and the unique trace element pattern of the Main Group of Sīrāf glasses is to argue that the Sīrāf glass was made from local sand, rich in chromium from the abundant chromite deposits in Yazd province just north of Sīrāf (Alipour 2017), but using imported plant ash from the Levant. Alternatively, one could consider whether the coastal plain around Sīrāf or its hinterland provides a different soil chemistry than the glass producing areas further north in Iraq and Iran, providing an environment closer to the soils of the Levant and their lowmagnesia plant ash. Only systematic fieldwork can resolve these questions.

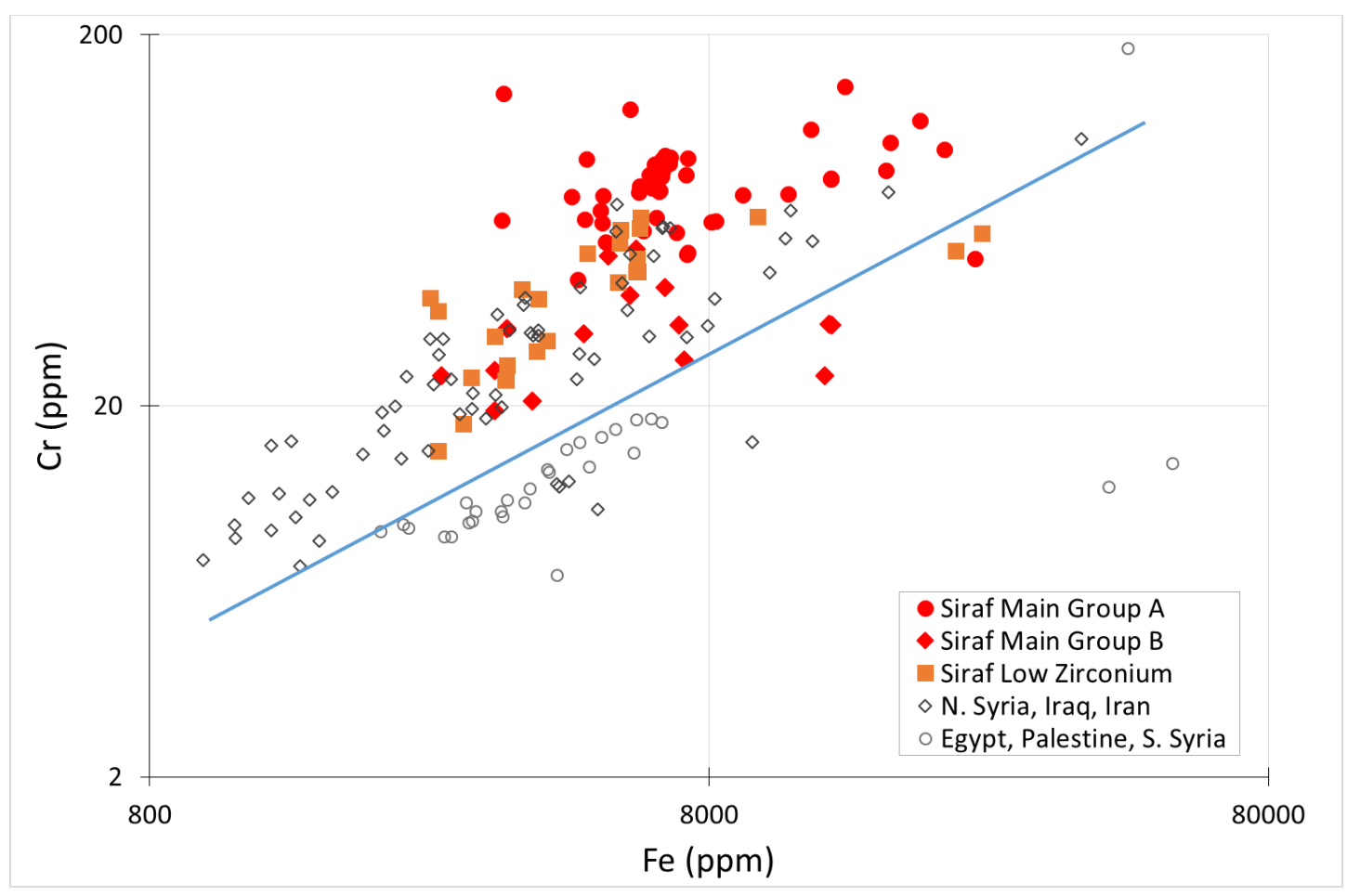



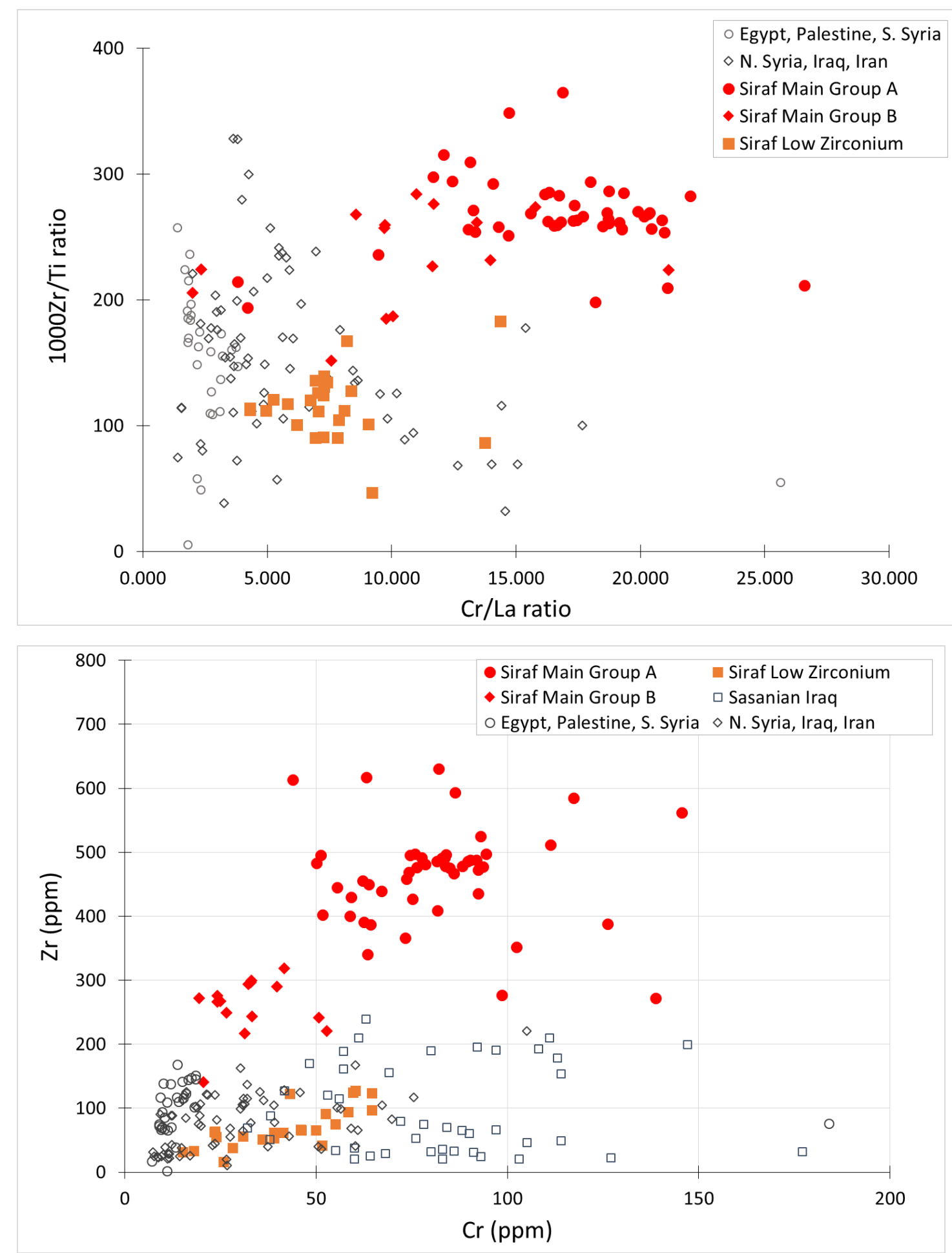

Figure 7a, 7b, and 7c: Scatterplot showing (a) chromium vs iron, (b) Cr/La ratio vs. $1000 \mathrm{Zr} / \mathrm{Ti}$ ratio, and (c) zirconium vs chromium for the Sìräf vessel glasses (not including bangles or kohl stick) compared to published data of Islamic glass from Egypt, Palestine, and southern Syria (the sites of Beirut, Damascus, Khirbat al-Minyā, and Cairo; data from Henderson et al. 2016), Islamic glass from northern Syria, Iraq, and northern Iran (the sites of Raqqa, Ctesiphon, Sāmarrā', and Nīshāpur; data from Henderson et al. 2016), and Sasanian glass (the site of Veh Ardašìr; data from Mirti et al. 2009). Scatterplots $7 a$ and $7 b$ are prepared after Henderson et al. 2016: 141, Fig. 5-6. 
The Low Zirconium Sīrāf samples are much more secure in their compositional similarity with glasses from contemporaneous $\left(9^{\text {th }}-10^{\text {th }}\right.$ century) sites in Iraq and Iran such as Ctesiphon, Sāmarrā', and Nīshāpur in terms of the major, minor, and trace elements (Henderson et al. 2016; for Nīshāpur see also Brill 1995, Brill 1999, and Wypyski 2015). The Low Zirconium Sīrāf samples are almost certainly the "east Persian" type that Whitehouse described, some of which he said are high-quality colourless glasses (often cut or carved) with a visual "family resemblance" to Nīshāpur glass; many of the Sīrāf Low Zirconium glasses are colourless or nearly-colourless (i.e. with a pale yellow, blue, or green tinge) and most seem to have been made with fresh glass rather than recycled glass. By plotting alumina and the ratio of magnesia to lime, Freestone et al. (2017) have recently defined two varieties of glass for samples from sites in Iraq and Iran, which they term "Mesopotamian Type 1" and "Mesopotamian Type 2", the former of which seems to correspond to what has been defined as Type B glasses at Nīshāpur and Sāmarrā' (Wypyski 2015) and the latter of which seems to correspond to what has been defined as Type A glasses at Nīshāpur and Sāmarrā' (Wypyski 2015) and PA-2 at Raya/al-Țūr in the Sinai Peninsula (Kato et al. 2010) as well as to some samples at Fusțāt in Egypt (see Wypyski 2015: 131). Almost all of the Sīrāf Low Zirconium glasses plot with this "Mesopotamian Type 1" glass, while the five Low Zirconium Sīrāf samples with less than $1.5 \mathrm{wt} \% \mathrm{Al}_{2} \mathrm{O}_{3}$ (samples siraf_019, 029, 091, 097, and 098 as previously mentioned) plot with the "Mesopotamian Type 2" glass (Figure 6b).

Three of the four dark blue glass samples from Sīrāf are made from Low Zirconium glass, including the bottle with a cylindrical neck (siraf_009; Figure 2, right) that was previously noted as a widespread type in the Early Islamic period. Two dark blue Low Zirconium Sīrāf glasses (siraf_009 and siraf_033) appear to plot better with the Syria-Palestinian glasses (Figure 6a and Figure 6b); these samples have somewhat lower magnesia and potash, and are similar to the Nīshāpur Type D glasses described by Wypyski (2015: 128-129) and likely also the PA-1 at Raya/al-Tūr in the Sinai Peninsula (Kato et al. 2010), which have possible links to Egypt or Syria-Palestine (Wypyski 2015: 132).

\subsection{Working debris}

At Site D, excavators noted that a "kiln and rubbish pit" contained large quantities of glassworking debris of the glass type visually most common at Sīrāf (Whitehouse 1968: 1214). Samples siraf_001-003, siraf_007, siraf_010-018 (Figure 2, left), and siraf_036-044 appear to be this type of debris described by Whitehouse; while these fragments have no recorded excavation context, the objects almost certainly come from Site D. Brill recalls that some of the fragments he collected were pulled from an exposed bank face that seemed to contain large amount of glass waste or even partially fused glass, and this description fits extraordinarily well archaeologically with the features of Site D as described by Whitehouse: "the [pottery] factory was discovered because marine erosion has encroached on the site, revealing walls, pottery kilns and rubbish pits in the face of a low cliff. We decided to carry out a limited investigation to record the features revealed by erosion before they were completely destroyed" (1968: 12).

Of the 22 fragments in the Corning Museum of Glass collection that have been identified as being related to glassworking (working debris, waste glass, cullet, or chunks), the chemical composition of 19 samples correspond to the Main Group (A) glass type and three to the 
Main Group (B) glass type. The compositional match between the working debris and the majority of the vessel glass fragments in the collection is of great interest, given that we interpret the Main Group here to be what Whitehouse described as the "local" (locallydominant) glass type.

We consider these chemical and archaeological observations to be strongly indicative of local glassworking on the site. It is unlikely that working waste would have been imported into Sīrāf alongside finished objects; instead, we suggest that either raw glass chunks of this composition were imported and worked locally, or that the Main Group glass was indeed locally produced (within the city itself or its hinterland) as well as worked at the site. It is potentially significant that samples with recycling indicators such as elevated levels of base metals (Jackson 1995) are generally rare among the Main Group glasses (12 out of 64 samples) and that only two pieces out of 22 examples of working debris have such indicators (siraf_015 and siraf_038). Thus, it seems that the working waste is primarily from processing fresh raw glass, rather than recycled cullet.

\subsection{Bangles, kohl stick, and outlier vessel fragments}

Beyond determining whether Whitehouse's visual groupings of the glass can be confirmed using chemical data, another key question is whether or not the bangles form any coherent compositional groups(s) that might be reflective of their distinctive function as jewellery, of their particular chronology at the site, or of their geographic provenance. The bangles from Sīräf in the Corning Museum of Glass were collected from two sites: Site F (residential buildings) and Site B (congregational mosque); all of these objects, however, are surface finds and thus largely postdate the main phasing of these structures. Whitehouse notes that two additional types of glass begin to appear in later, post- $10^{\text {th }}$ century, contexts at Sīrāf: bangles and vessels with a blue-green fabric (1968: 19). Combining the chemical and archaeological evidence, it seems probable that the bangles and outlier fragments are these later types of glass. The chemical data confirms that the bangles are indeed distinctive from the majority of the glass vessels that were analysed, and supports the hypothesis that this relates to their chronology; in the case of the high alumina glasses, compositional differences reflect production origin as well. Because the bangles are quite similar in composition to the outlier fragments, any compositional differences between the bangles and outliers may have to do with specific object categories (e.g. Swan et al. accepted), specifically, the use of a glass richer in soda and increased evidence for recycling may relate to the working properties and processes particular to bangle-making (e.g. Duckworth et al. 2016).

The low manganese ( $<0.2 \mathrm{wt} \% \mathrm{MnO}$ ) content of the eight bangles, four vessel fragments, and single kohl stick is significant, and that the three high alumina glasses also have low manganese further underscores the separate character of the low manganese glasses in relation to the majority of the glasses that were analysed (Figure 8). Small amounts of manganese are sometimes naturally present as an impurity in glassmaking raw materials, and more than $0.2 \mathrm{wt} \% \mathrm{MnO}$ indicates the intentional addition of manganese to a glass (Sayre 1963; compare 0.5 wt\% MnO in Brill 1995 and Jackson 2005). With the exception of the bangles, kohl stick, and outlier vessel fragments, manganese is present in the Sīrāf glasses at levels that suggest its deliberate addition to the glass batch, in glasses of all colours (Figure 9). 78 samples contain $0.5 \mathrm{wt} \% \mathrm{MnO}$ or more and 65 contain $1 \mathrm{wt} \% \mathrm{MnO}$ or more. Taken 
together with the archaeological interpretations of Whitehouse, we suggest the glasses at Sīrāf with low manganese represent a different chronological period and/or origin of glassmaking. The practice of deliberately adding manganese to the glass batch appears to have increased in the Early Islamic period. Evidence from the raw glass slab at Bet She'arim (Freestone et al. 2000: 71), the primary glassmaking workshops at Tyre (Freestone 2002: 72), and the glassmaking factory at Raqqa (Henderson et al. 2004: 461) indicate that manganese was added by primary glassmakers at the batch stage. There is also literary evidence that mentions the deliberate addition of manganese oxide to Islamic glasses, for example a large number of recipes in the ca. $8^{\text {th }}$-century treatise Kitāb al-Durra al-Maknūna by the polymath Jābir ibn Hayyān describe the addition of manganese when producing a variety of glass colours (al-Hassan 2009a: 140, see discussion in note 91; al-Hassan 2009b: 191-234). The chemical analysis of glass artefacts has also repeatedly demonstrated the high manganese content of Islamic glasses in comparison to many earlier glasses: Islamic glasses generally contain 0.5-1.5 wt\% MnO (Brill 2001: 29) and specific examples from around the Muslim world include an average of $1 \mathrm{wt} \% \mathrm{MnO}$ in glasses excavated at the site of $10^{\text {th }}-13^{\text {th }}$-century Banias in Israel (Freestone et al. 2000), $0.55 \mathrm{wt} \% \mathrm{MnO}$ in glasses excavated at $9^{\text {th }}-10^{\text {th }}$ century Nīshāpur (Brill 1995), $0.86 \mathrm{wt} \% \mathrm{MnO}$ in glasses excavated at the $8^{\text {th }}-12^{\text {th }}$-century site of Kush in the Emirate of Ras al-Khaimah (Swan unpublished data), $1.2 \mathrm{wt} \% \mathrm{MnO}$ in glasses recovered from the $11^{\text {th }}$-century Serçe Liman 1 shipwreck off the southern coast of Turkey (Brill 2009), and $1.3 \mathrm{wt} \% \mathrm{MnO}$ in $9^{\text {th }}-12^{\text {th }}$ century glasses excavated in Cordoba in Spain (Duckworth et al. 2015).

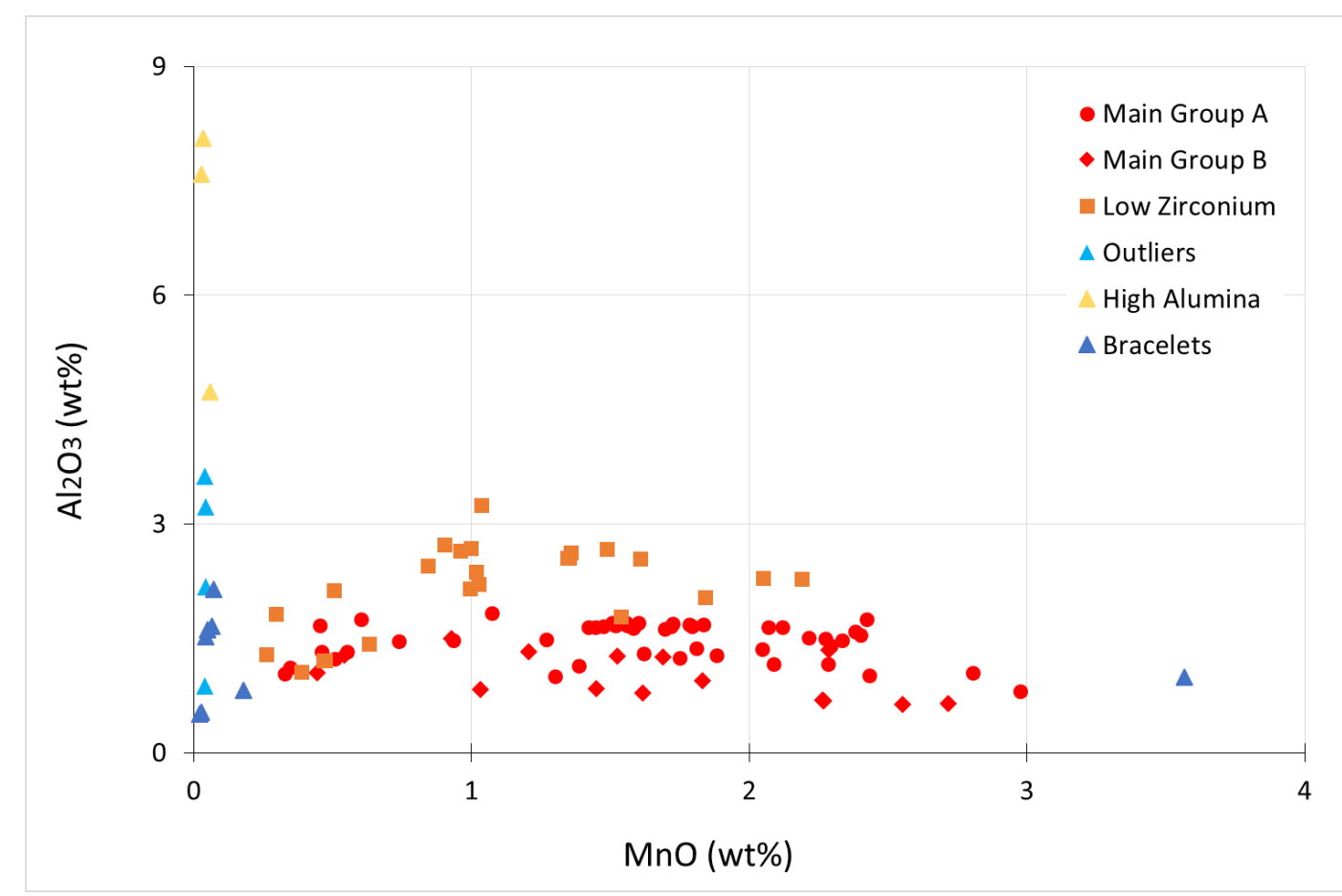

Figure 8: Scatterplot showing alumina vs manganese of the Sirräf glasses, demonstrating the differences between the glass types discussed. 


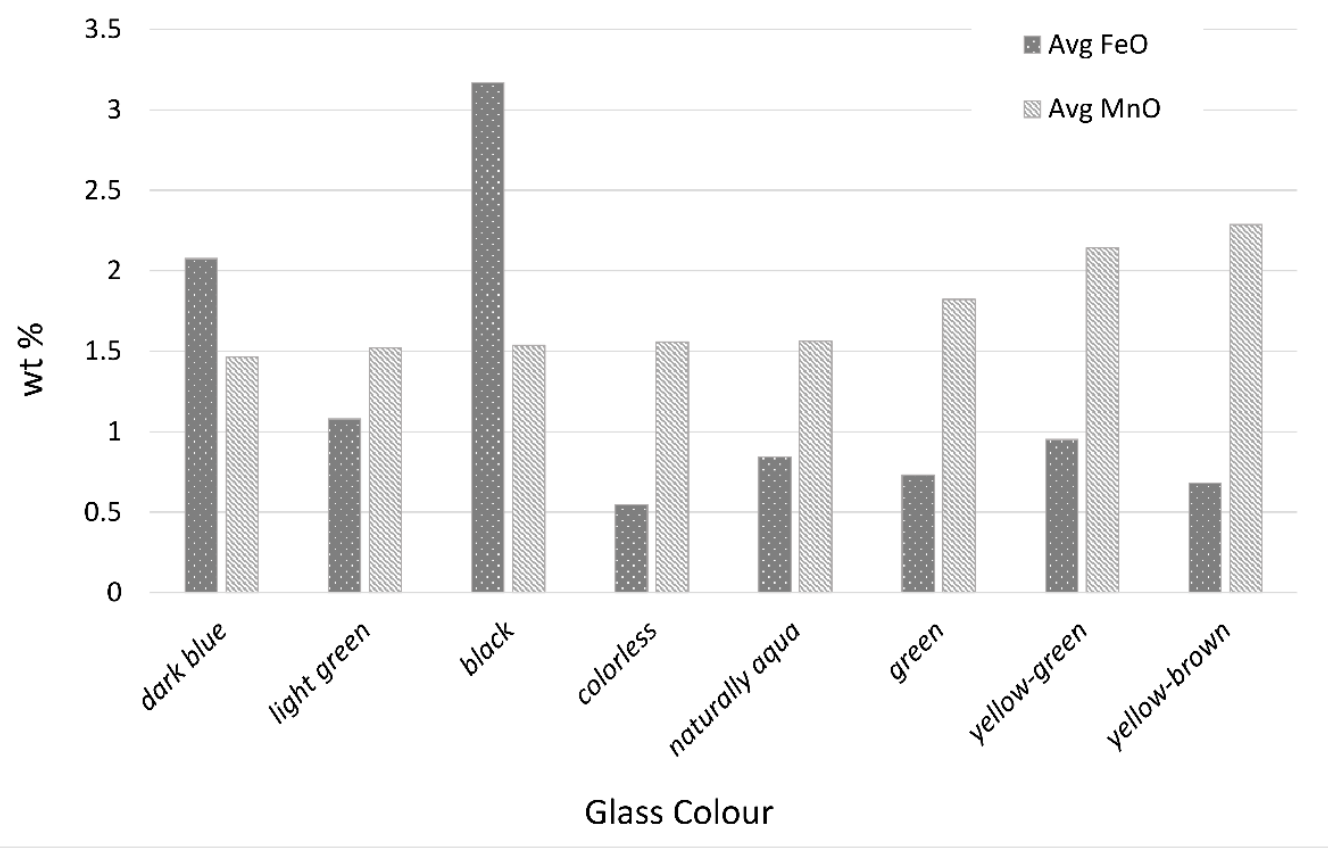

Figure 9: Average iron and manganese content of the Sìrāf samples, by glass colour.

Although only three of the 101 analysed Sīrāf glasses have a high alumina content, the presence of high-alumina soda glasses at Sīrāf is significant because they have been tied largely to South Asia, Southeast Asia, and Africa (Dussubieux et al. 2010) rather than to the Middle East or Iran. This is of great interest given Sīräf's geographic location and prominent role within the Indian Ocean trading network. The three fragments represent two different types of high-alumina glass. The first high-alumina type (kohl stick fragment siraf_090 and bangle fragment siraf-094) has high magnesia and very high potash and is likely be made with soda from plant ashes (v-Na-Al in Dussubieux et al. 2010); it is noteworthy that the kohl stick fragment is a stratified find that comes from a $14^{\text {th }}$ to $15^{\text {th }}$-century house context, while the bangle fragment is a surface find and thus likely to be of a similarly-late date at the site. Glass bangles with high alumina, potash, and iron but with lower lime and titania were excavated from Mamluk-Ottoman contexts at the sites of Tell Abu Sarbut and Khirbat Faris in Jordan (Boulogne and Henderson 2009). High-alumina plant ash glasses have been identified at $9^{\text {th }}$-century sites on Madagascar (Robertshaw et al. 2006), Sumatra (Dussubieux 2009), and Kenya (Dussubieux and Kusimba 2012); from the archaeological and chemical evidence, it seems reasonable to believe the high-alumina glasses found in East Africa were not produced in that location, but were trade items made in South Asia. The second type of high-alumina glass (bangle fragment siraf_075) has the lowest magnesia, potash, and lime as well as the highest soda content of any of the Sīräf glasses. The low potash and lime combined with the high soda suggest that siraf_075 was made with mineral soda mixed with sand, as described in Dussubieux et al. 2010; as was noted in that study, reh is rich in soda and low in calcium and magnesium, and a poorly-refined granitic sand would contain relatively high levels of alumina, iron, titanium, and trace elements such as uranium (Dussubieux et al. 2010: 1647). Siraf_075 fits well with this characterization: it contains 26 ppm uranium while the other Sīrāf glasses contain only negligible traces of this element, 
typically around $1 \mathrm{ppm}$. Of the five high-alumina glass types outlined in Dussubieux et al., siraf_075 is most similar to m-Na-Al 2, a glass type that was identified at sites located on the west coast of India as well as the east coast of Africa dating to the $9^{\text {th }}-19^{\text {th }}$ centuries (Dussubieux et al. 2010: 1650).

\subsection{Principal Components Analysis and Cluster Analysis}

In addition to classifying the Sīrāf glasses by $\mathrm{Zr}, \mathrm{Cr}$, and $\mathrm{Mn}$, we investigated the contribution of additional elements in forming chemical compositional groups using multivariate statistical techniques, namely PCA (Principal Components Analysis) and CA (cluster analysis). While the PCA and CA results generally support the groups formed by $\mathrm{Zr}$ and $\mathrm{Cr}$ alone, there are a few distinctions worthy of comment. For the analyses presented here, we have included the major, minor, and trace elements (as oxides) $\mathrm{Si}, \mathrm{Na}, \mathrm{K}, \mathrm{Mg}, \mathrm{Ca}, \mathrm{Al}, \mathrm{Li}, \mathrm{B}$, $\mathrm{Ti}, \mathrm{V}, \mathrm{Cr}, \mathrm{Rb}, \mathrm{Sr}, \mathrm{Y}, \mathrm{Zr}, \mathrm{Ba}, \mathrm{La}, \mathrm{Ce}, \mathrm{Nd}, \mathrm{Eu}, \mathrm{Dy}$, Th and U, purposely avoiding those elements likely to act as or correlate with colorants or decolourants ( $\mathrm{Mn}, \mathrm{Cu}, \mathrm{Co}, \mathrm{Ni}, \mathrm{Zn}, \mathrm{As}$ ) or strongly affected by reheating and recycling $(\mathrm{P}, \mathrm{Cl})$. For both PCA and $\mathrm{CA}$, all oxides were first converted to logratio values; PCA was computed as a covariance matrix and CA using the average linkage method with Euclidean distances, and all graphs were produced using Minitab 17.

By both PCA and CA, the Sīrāf glasses may be divided into five groups. Figure 10a is a 'loading plot' for principal component (PC) 2 by PC1, showing that for PC1, Zr, Rb, Al, Mg and Ba provide most of the variability, with $\mathrm{Ti}, \mathrm{U}, \mathrm{Y}$ and $\mathrm{Cr}$ generally in line with $\mathrm{Zr}$. On the other hand, PC2 strongly reflects variation in Ba, associated with rare earths $\mathrm{La}, \mathrm{Ce}$, Eu and $\mathrm{Nd}$, and the light elements $\mathrm{Li}, \mathrm{B}, \mathrm{Na}, \mathrm{K}, \mathrm{Mg}$ and Si. Figure 10b, the 'score plot' of PC2 by PC1, maps the distribution of the Sīrāf samples within this two-dimensional space, where samples to the left will be higher in $\mathrm{Zr}$ and its associated elements, and samples to the right will be low in $\mathrm{Zr}$ but higher in such elements as $\mathrm{Ba}, \mathrm{Al}, \mathrm{Rb}$ and $\mathrm{Mg}$. We would expect the glasses in the upper part of the graph to contain higher levels of $\mathrm{Ba}$ and REEs, while those in the lower quadrants tend to be low in Ba but higher in light elements. Because PC1 and PC2 together incorporate only $67.8 \%$ of the total variability, some of the samples that seem very similar in Figure 10b will separate in a three or higher dimensional space. In terms of the biplots discussed earlier in the paper, the PCA analysis supports the use of $\mathrm{Zr}$ as an important variable, while $\mathrm{Cr}$ contributes less to the overall variability.

Figure 10b combines three types of data: first is the distribution of the glasses based on our selected variables; second the identification of the samples by compositional groups A, B, LM, LZ and O; and third the cluster number, 1 through 5, resulting from cluster analysis using these same variables and a similarity index set at $60 \%$, a level that will group similar glasses but with the expectation that these groups will still contain considerable variability. Most of the Sīrāf glasses fall into two groups with a clear separation. The first group, indicated by blue circles and red squares, forms cluster 1 by $\mathrm{CA}$, and includes all cullet and working waste samples, many of the vessels, and no bangles. The second large group, represented by purple and black triangles and green diamonds, cluster 2, includes all the low$\mathrm{Zr}$ glasses, as well as three of the outliers and five of the low-Mn bangles. Clusters 3, 4 and 5 all contain four or fewer samples. Cluster 3 includes four Main Group samples: two from group A and two from group B. What sets these samples, all vessels, apart are their high Ba 
and REEs. Groups 4 (one bangle) and 5 (two bangles and one vessel) are similar to each other and very different from the above groups. These glasses are marked by the highest $\mathrm{Zr}$ values, coupled with low Ba and low REEs. It is important to note that although the PCA diagram Figure $10 \mathrm{~b}$ is similar to the separation of samples by $\mathrm{Zr}$ and $\mathrm{Cr}$, when both $\mathrm{Zr}$ and $\mathrm{Cr}$ are omitted from the list of variables, the PCA pattern is almost identical, the only difference being a few sample shifts from group A to group B or vice versa. The definition of high- and low-zirconium groups is unaffected, indicating that there are fundamental differences, not limited to $\mathrm{Zr}$ and $\mathrm{Cr}$, between the two groups. In addition, the separation into sub-groups $\mathrm{A}$ and $\mathrm{B}$ is much more important on the $\mathrm{y}$-axis, representing PC2, than on the $\mathrm{x}$-axis, PC1, where $\mathrm{Zr}$ has its main influence. This suggests that the separation into sub-groups is supported by the compositional data, but that elements other than $\mathrm{Zr}$ will be important in better defining these groups. Regarding manganese, low-Mn (LM) glasses are widely distributed by PCA and present in clusters 2, 4 and 5, groups that are very different in their overall compositions. As is clear also from discussion in this paper, low manganese by itself may not be a useful way to separate the Sīrāf samples.

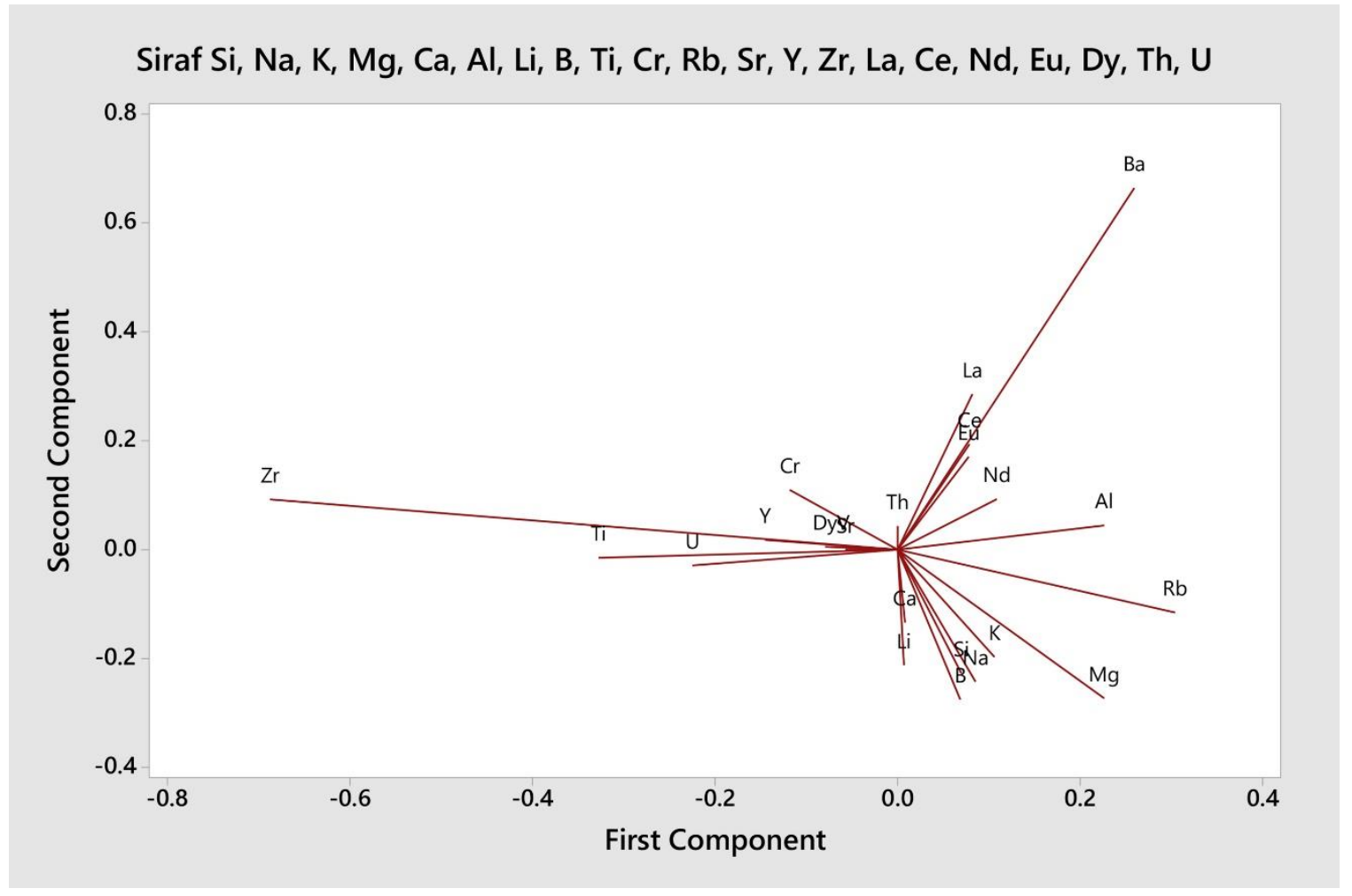

Figure 10a: Loading plot for PC1 and PC2 showing the relative contribution and directionality of the elements included in the PCA analysis of the Sìräf glasses, omitting the three high-alumina samples. 


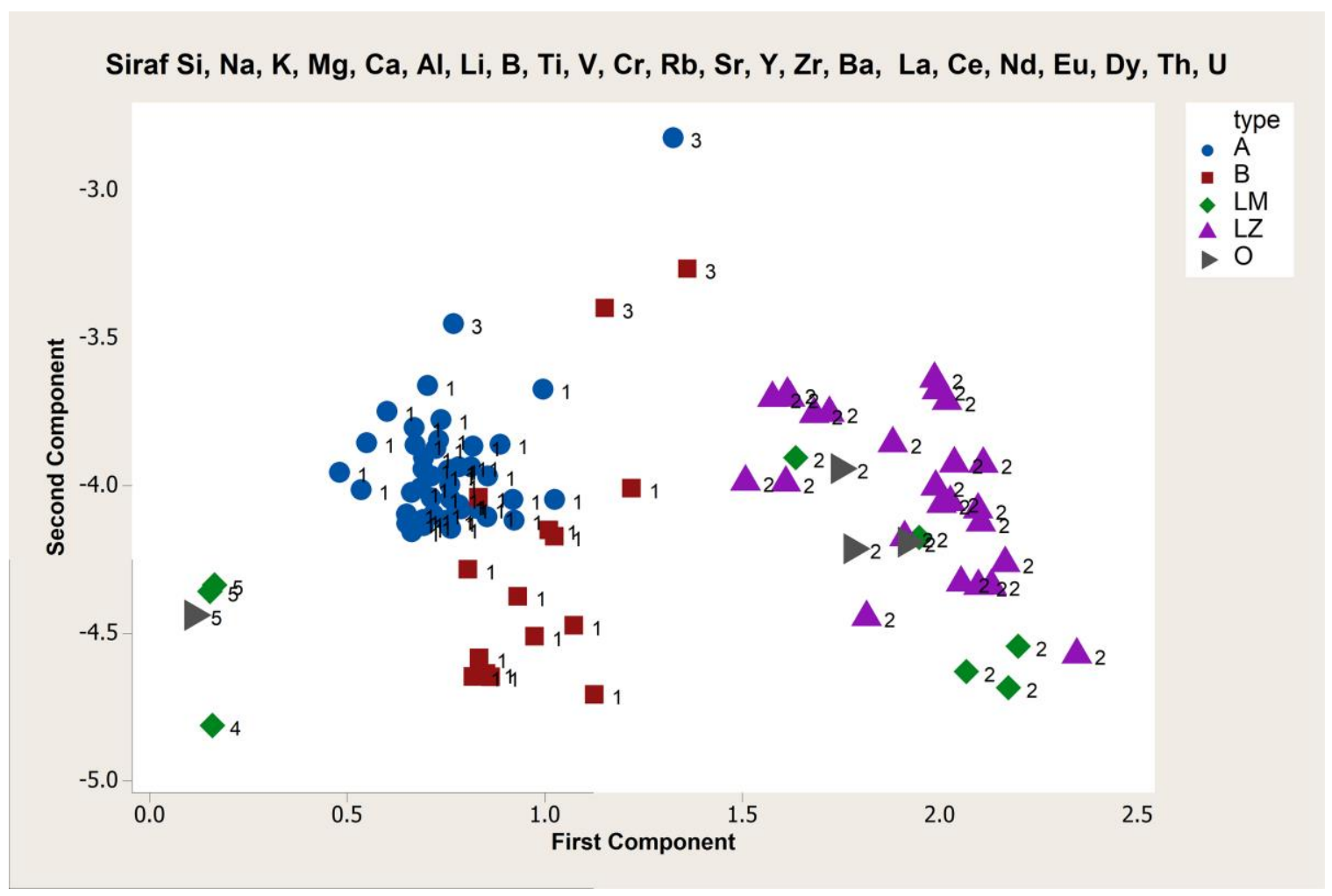

Figure 10b: Score plot for PC1 and PC2 incorporating data from our separation of the Sir $\bar{x} f$ samples into compositional groups based on $\mathrm{Zr}, \mathrm{Cr}$ and $\mathrm{Mn}$, as well as the results of preliminary cluster analysis; $A=$ Main Group A, B = Main Group B, LZ = Low Zirconium, $L M=$ Low Manganese, $O=$ Outlier.

\subsection{Sīrāf Main Group in context}

Earlier, we highlighted the apparent similarity of the Main Group of Sīrāf glass with plant ash glasses from sites in Syria-Palestine, in terms of their magnesia and potash concentrations (section 4.1 and Figures 6a and b). However, the exceptionally high zirconium and high chromium concentrations of the Sīrāf glass are in stark contrast to all published glasses from both Egypt and the Levant. A survey of published and our own unpublished data failed to find any matching samples. Thus, it seems rather unlikely that the origin of the Main Group of Sīrāf glass is the well-studied regions of Egypt or Syria-Palestine. Instead, we found that just over ten percent of the plant-ash glass samples from the contemporaneous sites of Mantai (Sri Lanka) and Thung Tuk (Thailand) are close matches to the Sīrāf Main Group (own unpublished data). These observations together strengthen the possibility that the locallydominating glass in Sīrāf was indeed locally produced for Sīrāfi consumption and some eastward trade, and further highlights the expanse of the Indian Ocean trade network of which Sīrāf was part (Lankton et al. forthcoming).

\section{Conclusions}

The purpose of this study was to explore the chemical characteristics and range of glass compositions present at Sīrāf, a major port in the south of Iran with wide-ranging trade links. 
We have shown that the glass can be grouped primarily by trace elements including zirconium and chromium, but also by minor oxides such as alumina, lime, and magnesia. This has led to the characterisation of a dominant Main Group comprising nearly 2/3 of all analysed finds and a subordinate Low Zirconium group comprising about 1/4 of all samples. The remaining samples (four vessels, a kohl stick, and eight bangles) display different chemical compositions that likely relate to the differing chronology and/or origin of the glass. The second goal of this study was to determine whether chemical analysis would bear out the visual interpretations that were made by Whitehouse during excavation (i.e. "local" glass, "east Persian" glass, and "Egyptian-origin" glass). We have shown that the dominant Main Group of glass, while superficially similar to Islamic plant ash glasses found in Egypt or Syria-Palestine, is potentially unique to Sīrāf and corresponds to Whitehouse's "local" type, while the Low Zirconium type with higher magnesia concentrations is similar to Sasanian and Islamic plant ash glass from Iraq and Iran and might correspond to Whitehouse's "east Persian" type. We were unable to match samples to Whitehouse's "Egyptian-origin" glass type. A third goal was to determine whether the bangles in particular were distinctive in any way from the other glasses. The chemical data appear to support the archaeology, in that the chronologically-later bangles have three distinctive compositions (two high alumina varieties, and a low manganese-high soda variety). The three high-alumina fragments resemble South Asian and East African glass with a potential Indian origin, commensurate with Sīrāf's role within the trading network operating in the Indian Ocean; one fragment comes from $14^{\text {th }}-15^{\text {th }}$ century stratigraphic contexts, suggesting that some glass objects (bangles, kohl sticks) were coming from South Asia during the later periods at Sīrāf.

Overall, the relative proportions of the different glass compositions mirror the central geographic position of Sīrāf: one can imagine glass coming from the core of the Islamic world (Mesopotamia, Persia) as well as from India into Sīrāf, and potentially locallyproduced glass being worked for both local use and to be shipped out via the Gulf port, eventually reaching as far as Sri Lanka and Thailand. In contrast, the bracelets (and potentially the low manganese glass vessels) appear at a later time when Sīrāf's importance as a hub of economic activity was declining; a steady glass supply from the West may have begun to dry up, so these items may have been brought in by merchants or sailors engaged in the Indian Ocean trade, either exchanged as currency or objects of personal adornment.

From our data and that of others it appears that intentionally-added manganese may be more common during the Islamic than, for example, during the Sasanian period, although there are clearly exceptions. The intentional addition of manganese in Islamic glasses of all colours has been noted for some time (e.g. Sayre and Smith 1961: 1826; Brill 1995), and does not seem to correlate with the colour of the glass. The Sīrāf samples that were visually identified as colourless have no higher $\mathrm{MnO}$ content than those characterised as light green, naturally aqua, etc. The presence of a few vessel fragments with lower manganese that otherwise match the Main Group and Low Zirconium glasses outlined above might indicate that the addition of manganese may not have been universally practiced by Islamic glassmakers. The circumstances and motivation for the addition of manganese to Islamic period glasses will be an important area for further study.

Overall, the study of Corning's Sīrāf glass fragments has demonstrated the information potential of legacy assemblages, in particular from areas currently less accessible for modern fieldwork, and the value of well-documented study collections to support ongoing research. 
More detailed interpretation of this particular dataset is made difficult by the lack of specific dating and typological study of artefacts that were probably surface finds; however, the uniqueness of the Main Group composition opens new avenues to trace the flow of this glass beyond the immediate Gulf region.

\section{Acknowledgements}

We are grateful to the Corning Museum of Glass for making accessible the glass fragments from Sīrāf. We also thank two anonymous reviewers for their very helpful comments. This paper was made possible by NPRP grant 7-776-6-024 from the Qatar National Research Fund (a member of Qatar Foundation). The statements made herein are solely the responsibility of the authors.

\section{References}

Alipour, R. 2017. Persian crucible steel production: Chāhak tradition. Unpublished PhD thesis University College London.

Barkoudah, Y., and Henderson, J. 2006. "Plant ashes from Syria and the manufacture of ancient glass: ethnographic and scientific aspects." Journal of Glass Studies 48: 297-321.

Boulogne, S., and Henderson, J. 2009. "Indian Glass in the Middle East? Medieval and Ottoman Glass Bangles from Central Jordan.” Journal of Glass Studies 51: 53-75.

Brill, R. H. 1988. "Scientific investigations of the Jalame glass and related finds." In: Weinberg, G. D. (ed.), Excavations at Jalame, site of a glass factory in late Roman Palestine, Columbia, MO, University of Missouri Press, 205-206.

Brill, R. H. 1995. "Appendix 3: Chemical Analyses of Some Glass Fragments from Nīshāpur in the Corning Museum of Glass.” In: Kröger, J., Nishapur: Glass of the Early Islamic Period, New York, The Metropolitan Museum of Art, 211-233.

Brill, R. H. 1999a. Chemical Analyses of Early Glasses. Volume 1: The Catalogue. Corning: The Corning Museum of Glass.

Brill, R. H. 1999b. Chemical Analyses of Early Glasses. Volume 2: The Tables. Corning: The Corning Museum of Glass.

Brill, R. H. 2001. "Some Thoughts on the Chemistry and Technology of Islamic Glass." In: Carboni, S., and Whitehouse, D. (Eds.), Glass of the Sultans, New York, The Metropolitan Museum of Art, 25-45.

Brill, R. H. 2009. “Chemical Analyses.” In: Bass, G. F., Brill, R. H., Lledó, B., and Matthews, S. D., Serçe Limant: Vol. 2, The Glass of an Eleventh-Century Shipwreck, College Station, Texas A\&M University Press, 459-496.

Cagno, S., Cosyns, P., Nys, K., and Janssens, K. 2013. "Black-Appearing Roman Glass.” In: Janssens, K. (ed.), Modern Methods for Analysing Archaeological and Historical Glass, Chichester, John Wiley \& Sons, 369-385. 
Carboni, S. 2013. “The Mantai Glass.” In: Carswell, J., Deraniyagala, S., and Graham A. (eds.), Mantai. City by the Sea, Linden Soft Verlag, 313-348.

Duckworth, C. N., De la Llave, R. C., Faber, E. W., Govantes Edwards, D. J., and Henderson, J. 2015. "Electron Microprobe Analysis of $9^{\text {th }}-12^{\text {th }}$ Century Islamic Glass from Córdoba, Spain.” Archaeometry 57: 27-50.

Duckworth, C. N., Mattingly, D., Chenery, S., and Smith, V. C. 2016. "End of the Line? Glass Bangles, Technology, Recycling, and Trade in Islamic North Africa." Journal of Glass Studies 58: 135-169.

Dussubieux, L. 2009. "Compositional analysis of ancient glass fragments from North Sumatra." In: Perret, D., and Surachman, H. (eds.), Histoire de Barus III. Regards sur une place marchande de l'océan Indien. École Française d'Extrême-Orient, XIIe-milieu du XVIIe s. Association Archipel (Cahier d'Archipel 38), Paris, 385-417.

Dussubieux, L., Gratuze, B., and Blet-Lemarquand, M. 2010. "Mineral Soda Alumina glass: Occurrence and Meaning." Journal of Archaeological Science 37: 1646-1655.

Dussubieux, L., and Kusimba, C. M. 2012. "Glass Vessels in Sub-Saharan Africa: a Compositional Study of Samples from Mtwapa Kenya.” In: Liritzis, I., and Stevenson, C. M. (eds.), Obsidian and Ancient Manufactured Glasses. Albuquerque: University of New Mexico Press, 143-156.

Foy, D., Picon, M., Vichy, M., and Thirion-Merle, V. 2003b. "Charactérisation des Verres de la Fin de l'Antiquité en Mediterranée Occidentale: 1'Emergence de Nouveaux Courants Commerciaux." In: Foy, D., and Nenna M.-D. (eds.), Échanges et Commerce du Verre dans le Monde Antique, Montagnac, Monique Mergoil, 41-85.

Freestone, I. C. 2005. "The Provenance of Ancient Glass through Compositional Analysis." In: Vandiver, P., Mass, J., and Murray, A. (eds.), Materials Issues in Art and Archaeology VII, Materials Research Society Symposium Proceedings 852, Warrendale, Materials Research Society, 195-208.

Freestone, I. C. 2006. "Glass production in Late Antiquity and the Early Islamic period: A Geochemical Perspective." In: Maggetti, M., and Messiga, B. (eds.), Geomaterials in Cultural Heritage, London, Geological Society of London Special Publication 257, 201-216.

Freestone, I. C. 2015. "The Recycling and Reuse of Roman Glass: Analytical Approaches." Journal of Glass Studies 57: 29-40.

Freestone, I. C., Gorin-Rosen, Y., and Hughes, M. J. 2000. "Primary Glass from Israel and the Production of Glass in Late Antiquity and the Early Islamic Period." In: Nenna, M-D. (ed.), La Route du Verre: Ateliers Primaires et Secondaires du Second Millénaire av. J.-C. au Moyan Âge, Lyon, Maison de l'Orient Mediterranéen No. 33, 65-83.

Freestone, I. C., Greenwood, R., and Gorin-Rosen, Y. 2002. "Byzantine and Early Islamic glassmaking in the Eastern Mediterranean: production and distribution of primary glass." In: Kordas, G. (ed.), Hyalos-Vitrum-Glass, $1^{\text {st }}$ International Conference: History, Technology and Conservation of Glass and Vitreous Materials in the Hellenic World, Athens, Glasnet Publications, 167-174. 
Freestone, I. C., Wolf, S., and Thirlwall, M., 2005. "The production of HIMT glass: elemental and isotopic evidence." In: Annales du 16 e Congrès de l'Association Internationale pour l'Histoire du Verre, 153-7, AIHV, London.

Freestone, I., Phelps, M., Simpson, St. J., and Gratuze, B. 2017. "Analytical Investigation of Early Islamic Glass from Sir Bani Yas (United Arab Emirates).” Paper presentation given at the Seminar for Arabian Studies, British Museum, 4-6 August 2017.

Gratuze, B. 2013. "Glass Characterisation Using Laser Ablation Inductively Coupled Plasma Mass Spectrometry Methods.” In: Janssens, K. (ed.), Modern Methods for Analysing Archaeological and Historical Glass, Volume I, Chichester, Wiley, 201-234.

Gratuze, B. 2016. "Glass Characterisation Using Laser Ablation Inductively Coupled Plasma Mass Spectrometry Methods. In: Dussubieux, L., Golitko, M., and Gratuze, B. (eds.), Recent Advances in Laser Ablation ICP-MS for Archaeology, Berlin, Springer 179-196.

al-Hassan, A. Y. 2009a. "An Eighth Century Arabic Treatise on the Colouring of Glass: Kitāb al-Durra al-Maknūna (The Book of the Hidden Pearl) of Jābir ibn Hayyān (ca. 721-c. 815)." Arabic Sciences and Philosophy 19: 121-156.

al-Hassan, A. Y. 2009b. Studies in al-Kimya'. Critical Issues in Latin and Arabic Alchemy and Chemistry. Hildesheim: Georg Olms Verlag.

Hasson, R. 1979. Early Islamic Glass. Jerusalem: L.A. Mayer Memorial Institute for Islamic Art.

Heck, M., Rehren, Th., and Hoffmann, P. 2003. "The production of lead-tin yellow at Merovingian Schleitheim (Switzerland).” Archaeometry 45: 33-44.

Henderson, J., McLoughlin, S. D., and McPhail, D. S. 2004. "Radical Changes in Islamic Glass Technology: Evidence for Conservatism and Experimentation with New Glass Recipes from Early and Middle Islamic Raqqa, Syria.” Archaeometry 46: 439-468.

Henderson, J., Chenery, S., Faber, E., and Kröger, J. 2016. "The use of electron probe microanalysis and laser ablation-inductively coupled plasma-mass spectrometry for the investigation of $8^{\text {th }}-14^{\text {th }}$ century plant ash glasses from the Middle East." Microchemical Journal 128: 134-152.

Jackson, C. M. 1995. "From Roman to Early Medieval Glasses: Many Happy Returns or a New Birth?” Annales du 13 Congrès de l'Association Internationale pour l'Histoire du Verre, Pays-Bas, 289-302.

Jackson, C. M. 2005. "Making Colourless Glass in the Roman Period." Archaeometry 47: 763-780.

Kato, N., Nakai, I., and Shindo, Y. 2010. "Transitions in Islamic Plant-Ash Glass Vessels: On-Site Chemical Analyses Conducted at the Raya/al-Tur area on the Sinai Peninsula in Egypt.” Journal of Archaeological Science 27: 1381-1395.

Khakzad, S., Trakadas, A., Harpster, M., and Wittig, N. 2015. "Maritime Aspects of Medieval Siraf, Iran: a Pilot Project for the Investigation of Coastal and Underwater Archaeological Remains." The International Journal of Nautical Archaeology 44: 258-276. 
Kröger, J. 1995. Nīshāpur: Glass of the Early Islamic Period. New York: The Metropolitan Museum of Art.

Lowick, N.M. 1985. Sìrāf XV. The Coins and Monumental Inscriptions. London: The British Institute of Persian Studies.

Mason, R. B., and Keall, E. J. 1991. "The 'Abbāsid Glazed Wares of Sīrāf and the Basra Connection: Petrographic Analysis." Iran 29: 51-66.

Mirti, P., Pace, M., Malandrino, M., and Negro Ponzi, M. 2009. "Sasanian glass from Veh Ardašīr: new evidence by ICP-MS analysis.” Journal of Archaeological Science 36: 10611069.

Möncke, D., Papageorgiou, M., Winterstein-Beckmann, A., and Zacharias, N. 2014. "Roman glasses coloured by dissolved transition metal ions: redox-reactions, optical spectroscopy and ligand field theory." Journal of Archaeological Science 46: 23-36.

Piacentini, V.F. 1992. Merchants, Merchandise and Military Power in the Persian Gulf (Suriyanj/Shakriyaj-Sìrāf). Rome: Atti della Accademia Nazionale dei Lincei, Serie IX, Vol. III (2).

Priestman, S. M. N. 2005. "The rise of Sīrāf: long-term development of trade emporia within the Persian Gulf." In Tabadar, E., and Mashayekhi, A. (eds.), Proceedings of the International Congress of Sìräf Port, November 14 - 16, 2005, Bushehr-Iran. Bushehr: Bushehr, Iran: Bushehr Branch of Iranology Foundation \& Bushehr University of Medical Sciences, 137-156.

Priestman, S. Forthcoming. Siraf: Excavated Finds in the British Museum. British Institute of Persian Studies Archaeological Monograph Series. Oxford: Oxbow.

Rehren, Th. 2016. “Another order for glass - or: how much glass does Pharaoh need?” In: Franzmeier, H., Rehren, Th., and Schulz, R. (eds.), Mit archäologischen Schichten Geschichte schreiben: Festscrift für Edgar B. Pusch zum 70. Geburtstag, Verlag Gebrüder Gerstenberg 257-267.

Robertshaw, P., Rasoarifetra, B., Wood, M., Melchiorre, E., Popelka-Filcoff, R.S., Glascock, M.D., 2006. "Chemical analysis of glass beads from Madagascar." Journal of African Archaeology 4: 91-109.

Sayre, E. V. 1963. "The Intentional Use of Antimony in Ancient Glasses," in Matson, F. R., and Rindone, G. (eds.), Advances in Glass Technology, part 2, New York, Plenum Press, 263-282.

Sayre, E. V., and Smith, R. W. 1961. "Compositional Categories of Ancient Glass.” Science Vol. 133, No. 3467: 1824-1826.

Silvestri, A., Molin, G., and Salviulo, G. 2008. "The Colourless Glass of Iulia Felix.” Journal of Archaeological Science 35: 331-341.

Simpson, St. J. 2014. "Sasanian glass: an overview.” In: Keller, D., Price, J., and Jackson, C. (eds.), Neighbours and Successors of Rome: Traditions of Glass Production and Use in Europe and the Middle East in the Later $1^{\text {st }}$ Millennium AD, Oxford, Oxbow Books, 200-231. 
Swan, C. M. Forthcoming. "An Archaeology of Glass and International Trade in the Gulf," In: Fromherz, A. (ed.), The Gulf: Global Contacts, Connections, and Cultures at the Crossroads of Persia and Arabia, Edinburgh, Edinburgh University Press.

Swan, C. M., Rehren, Th., Dussubieux, L., and Eger, A. A. 2017. "High-Boron and HighAlumina Middle Byzantine (10th-12th century CE) Glass Bracelets: Indications for a Western Anatolian Glass Industry." Archaeometry, doi: 10.1111/arcm.12314

Tabadar, E., and Mashayekhi, A. (eds.) 2005. Proceedings of the International Congress of Siraf Port: November 14 - 16, 2005, Bushehr-Iran. Bushehr, Iran: Bushehr Branch of Iranology Foundation \& Bushehr University of Medical Sciences.

Tampoe, M. 1989. Maritime Trade between China and the West: an Archaeological Study of the Ceramics from Siraf (Persian Gulf), $8^{\text {th }}$ to $15^{\text {th }}$ centuries A.D. Oxford.

Whitehouse, D. 1968. "Excavations at Sīrāf: First Interim Report.” Iran 6: 1-22.

Whitehouse, D. 1969. "Excavations at Sīrāf: Second Interim Report.” Iran 7: 39-62.

Whitehouse, D. 1970. "Excavations at Sīrāf: Third Interim Report.” Iran 8: 1-18.

Whitehouse, D. 1970. "Sīrāf: a medieval port on the Persian Gulf." World Archaeology 2: 141-158.

Whitehouse, D. 1971a. "Sīrāf: a Sasanian port.” Antiquity 45: 262-267.

Whitehouse, D. 1971b. "Excavations at Sīrāf: Fourth Interim Report.” Iran 9: 1-17.

Whitehouse, D. 1972. "Excavations at Sīrāf: Fifth Interim Report.” Iran 10: 63-87.

Whitehouse, D. 1974. "Excavations at Sīrāf: Sixth Interim Report.” Iran 12: 1-30.

Whitehouse, D. 1980. Sīrāf III. The Congregational Mosque and Other Mosques from the Ninth to the Twelfth Centuries (London, The British Institute of Persian Studies)

Whitehouse, D. 1983. Maritime trade in the Gulf: The 11th and $12^{\text {th }}$ centuries." World Archaeology 14: 328-334.

Whitehouse, D. 2009. Sìrāf: History, Topography, and Environment. Oxford: Oxbow Books.

Whitehouse, D. and Williamson, A. 1973. “Sasanian Maritime Trade.” Iran 11: 29-49.

Wood, N., and Priestman, S. 2016. "New Light on Chinese Tang Dynasty and Iraqi Blue and White in the Ninth Century: The Material from Siraf, Iran." Bulletin of Chinese Ceramic Art and Archaeology 7: 47-60.

Wypyski, M. T. 2015. “Chemical Analysis of Early Islamic Glass from Nīshāpur.” Journal of Glass Studies 57: 121-136. 
Table 1: Analytical results: major and minor oxides (in wt\%) and trace elements (in ppm).

[NOTE TO EDITOR THIS APPEARS ON NEXT PAGES. A separate Excel file will be uploaded; below the table as part of this document for reviewing purposes only.] 


\begin{tabular}{|c|c|c|c|c|c|c|c|c|c|c|c|c|c|c|c|c|c|c|}
\hline Sample ID & Object type & Colour & Glass group & $\mathrm{SiO2}$ & $\mathrm{Na2O}$ & $\mathrm{K2O}$ & MgO & Al203 & $\mathrm{CaO}$ & $\mathrm{FeO}$ & MnO & P2O5 & Cl & $\mathbf{L i}$ & $\mathbf{B}$ & $\mathbf{T i}$ & $\mathbf{V}$ & $\mathbf{C r}$ \\
\hline siraf_004 & vessel base & $\begin{array}{l}\text { light green- } \\
\text { colourless }\end{array}$ & Main group (A) & 68.8 & 13.5 & 2.88 & 2.07 & 0.80 & 7.00 & 0.44 & 2.98 & 0.28 & 0.81 & 14 & 102 & 1046 & 13 & 139 \\
\hline siraf_053 & vessel base & naturally aqua & Main group (A) & 65.5 & 13.9 & 2.65 & 2.02 & 1.67 & 9.00 & 2.71 & 0.45 & 0.43 & 0.68 & 24 & 85 & 1292 & 23 & 98 \\
\hline siraf_005 & vessel & naturally aqua & Main group (A) & 66.3 & 14.0 & 3.26 & 2.43 & 1.49 & 9.51 & 0.44 & 1.27 & 0.35 & 0.50 & 15 & 118 & 1300 & 15 & 63 \\
\hline siraf_055 & vessel & light green & Main group (A) & 66.8 & 13.7 & 2.87 & 2.29 & 1.32 & 8.74 & 2.17 & 0.55 & 0.34 & 0.58 & 21 & 97 & 1680 & 17 & 102 \\
\hline siraf_045 & vessel & light green & Main group (A) & 64.8 & 14.5 & 2.33 & 2.30 & 1.05 & 9.90 & 0.58 & 2.80 & 0.30 & 0.83 & 16 & 90 & 1846 & 18 & 73 \\
\hline siraf_062 & vessel & naturally aqua & Main group (A) & 68.1 & 12.8 & 2.28 & 2.74 & 1.28 & 8.62 & 0.83 & 1.88 & 0.25 & 0.67 & 21 & 100 & 1356 & 15 & 64 \\
\hline siraf_052 & vessel & yellow-green & Main group (A) & 67.0 & 12.6 & 2.46 & 2.48 & 1.30 & 10.12 & 0.74 & 1.62 & 0.36 & 0.67 & 15 & 91 & 1836 & 19 & 126 \\
\hline siraf_084 & vessel rim & naturally aqua & Main group (A) & 68.6 & 13.6 & 2.36 & 2.49 & 1.12 & 8.83 & 1.04 & 0.35 & 0.29 & 0.73 & 20 & 95 & 1656 & 16 & 62 \\
\hline siraf_059 & vessel & naturally aqua & Main group (A) & 66.7 & 13.6 & 2.56 & 2.89 & 1.50 & 8.07 & 0.90 & 2.22 & 0.27 & 0.59 & 18 & 101 & 1359 & 48 & 59 \\
\hline siraf_027 & vessel & naturally aqua & Main group (A) & 67.0 & 14.1 & 2.47 & 2.56 & 1.00 & 8.90 & 0.94 & 1.30 & 0.33 & 0.74 & 16 & 111 & 1561 & 15 & 52 \\
\hline siraf_032 & vessel rim & light green & Main group (A) & 68.4 & 12.2 & 2.75 & 2.34 & 1.75 & 8.68 & 1.70 & 0.60 & 0.33 & 0.51 & 17 & 108 & 1628 & 22 & 82 \\
\hline siraf_074 & unknown & green & Main group (A) & 66.8 & 12.6 & 2.08 & 3.07 & 1.59 & 8.90 & 0.77 & 2.38 & 0.34 & 0.89 & 23 & 130 & 1577 & 19 & 75 \\
\hline siraf_042 & chunk? & $\begin{array}{l}\text { light green- } \\
\text { aqua }\end{array}$ & Main group (A) & 66.8 & 12.3 & 2.02 & 3.09 & 1.74 & 9.19 & 0.78 & 2.42 & 0.31 & 0.76 & 24 & 115 & 1676 & 21 & 59 \\
\hline siraf_073 & unknown & green & Main group (A) & 66.8 & 13.6 & 3.09 & 2.09 & 1.65 & 8.39 & 0.62 & 2.07 & 0.32 & 0.77 & 15 & 99 & 1715 & 22 & 92 \\
\hline siraf_038 & chunk? & green & Main group (A) & 67.5 & 12.3 & 2.04 & 2.98 & 1.55 & 8.89 & 0.66 & 2.40 & 0.32 & 0.85 & 24 & 121 & 1595 & 20 & 67 \\
\hline siraf_037 & chunk? & $\begin{array}{l}\text { light green- } \\
\text { aqua }\end{array}$ & Main group (A) & 67.5 & 12.4 & 2.05 & 2.97 & 1.47 & 8.93 & 0.67 & 2.33 & 0.31 & 0.83 & 24 & 118 & 1640 & 19 & 55 \\
\hline siraf_039 & chunk? & green & Main group (A) & 67.7 & 12.2 & 2.03 & 3.00 & 1.50 & 8.90 & 0.62 & 2.27 & 0.33 & 0.87 & 24 & 123 & 1588 & 19 & 64 \\
\hline siraf_071 & unknown & light green & Main group (A) & 68.2 & 12.1 & 2.06 & 2.84 & 1.40 & 8.65 & 0.66 & 2.29 & 0.31 & 0.88 & 24 & 117 & 1606 & 19 & 62 \\
\hline siraf_072 & unknown & light green & Main group (A) & 68.7 & 12.3 & 2.11 & 2.77 & 1.38 & 8.53 & 0.66 & 1.81 & 0.32 & 0.91 & 25 & 118 & 1609 & 18 & 74 \\
\hline siraf_011 & $\begin{array}{l}\text { working } \\
\text { debris? }\end{array}$ & light green & Main group (A) & 66.1 & 13.8 & 2.99 & 2.21 & 1.66 & 9.11 & 0.85 & 1.72 & 0.31 & 0.60 & 15 & 104 & 1822 & 21 & 86 \\
\hline siraf_061 & vessel & yellow-green & Main group (A) & 70.3 & 11.5 & 2.54 & 1.99 & 1.17 & 7.75 & 1.18 & 2.09 & 0.30 & 0.57 & 13 & 82 & 1846 & 19 & 74 \\
\hline siraf_010 & $\begin{array}{l}\text { working } \\
\text { debris? }\end{array}$ & light green & Main group (A) & 65.7 & 13.9 & 2.99 & 2.25 & 1.68 & 9.18 & 0.85 & 1.84 & 0.31 & 0.63 & 17 & 104 & 1841 & 21 & 92 \\
\hline siraf_013 & $\begin{array}{l}\text { working } \\
\text { debris? }\end{array}$ & naturally aqua & Main group (A) & 66.0 & 13.9 & 2.96 & 2.22 & 1.67 & 9.13 & 0.83 & 1.59 & 0.32 & 0.69 & 16 & 106 & 1840 & 21 & 85 \\
\hline siraf_014 & $\begin{array}{l}\text { working } \\
\text { debris? }\end{array}$ & light green & Main group (A) & 66.2 & 13.8 & 2.97 & 2.22 & 1.67 & 9.30 & 0.84 & 1.56 & 0.32 & 0.49 & 16 & 99 & 1841 & 21 & 76 \\
\hline siraf_002 & vessel & light green & Main group (A) & 66.0 & 13.8 & 2.95 & 2.21 & 1.66 & 9.19 & 0.88 & 1.79 & 0.32 & 0.47 & 17 & 105 & 1812 & 21 & 94 \\
\hline siraf_041 & chunk? & naturally aqua & Main group (A) & 66.2 & 13.9 & 2.95 & 2.23 & 1.68 & 9.14 & 0.85 & 1.51 & 0.33 & 0.63 & 18 & 105 & 1793 & 21 & 88 \\
\hline siraf_063 & vessel & indeterminate & Main group (A) & 66.0 & 14.0 & 3.00 & 2.21 & 1.64 & 9.09 & 0.80 & 1.58 & 0.32 & 0.72 & 17 & 104 & 1809 & 20 & 84 \\
\hline siraf_018 & $\begin{array}{l}\text { working } \\
\text { debris? }\end{array}$ & light green & Main group (A) & 66.1 & 13.9 & 2.98 & 2.21 & 1.63 & 9.06 & 0.77 & 1.70 & 0.31 & 0.71 & 15 & 102 & 1855 & 21 & 78 \\
\hline siraf_085 & vessel base & light green & Main group (A) & 68.2 & 13.4 & 2.11 & 2.20 & 1.24 & 7.14 & 3.08 & 0.51 & 0.30 & 0.80 & 26 & 95 & 2494 & 16 & 50 \\
\hline
\end{tabular}




\begin{tabular}{|c|c|c|c|c|c|c|c|c|c|c|c|c|c|c|c|c|c|c|}
\hline siraf_040 & $\begin{array}{l}\text { working } \\
\text { debris? }\end{array}$ & naturally aqua & Main group (A) & 66.3 & 13.8 & 2.98 & 2.23 & 1.66 & 9.18 & 0.82 & 1.48 & 0.31 & 0.64 & 17 & 101 & 1846 & 21 & 81 \\
\hline siraf_003 & vessel & green & Main group (A) & 66.1 & 14.0 & 3.01 & 2.24 & 1.65 & 9.27 & 0.82 & 1.42 & 0.32 & 0.55 & 17 & 104 & 1814 & 21 & 90 \\
\hline siraf_001 & cullet & green & Main group (A) & 65.9 & 14.0 & 3.03 & 2.30 & 1.83 & 9.42 & 0.88 & 1.07 & 0.33 & 0.64 & 17 & 107 & 1869 & 22 & 90 \\
\hline siraf_012 & $\begin{array}{l}\text { working } \\
\text { debris? }\end{array}$ & light green & Main group (A) & 65.4 & 14.1 & 2.99 & 2.33 & 1.71 & 9.55 & 0.86 & 1.51 & 0.30 & 0.64 & 17 & 100 & 1903 & 21 & 92 \\
\hline siraf_016 & $\begin{array}{l}\text { working } \\
\text { debris? }\end{array}$ & green & Main group (A) & 66.1 & 13.8 & 2.99 & 2.23 & 1.67 & 9.20 & 0.85 & 1.52 & 0.31 & 0.67 & 16 & 102 & 1867 & 21 & 83 \\
\hline siraf_017 & $\begin{array}{l}\text { working } \\
\text { debris? }\end{array}$ & green & Main group (A) & 66.3 & 13.8 & 2.98 & 2.22 & 1.65 & 9.08 & 0.81 & 1.44 & 0.32 & 0.70 & 15 & 104 & 1871 & 21 & 78 \\
\hline siraf_036 & $\begin{array}{l}\text { working } \\
\text { debris? }\end{array}$ & light green & Main group (A) & 66.1 & 13.6 & 2.93 & 2.21 & 1.68 & 9.24 & 0.83 & 1.79 & 0.31 & 0.64 & 16 & 101 & 1844 & 21 & 84 \\
\hline siraf_024 & vessel & naturally aqua & Main group (A) & 66.2 & 13.8 & 2.51 & 2.92 & 1.36 & 8.69 & 0.94 & 2.05 & 0.24 & 0.56 & 24 & 118 & 1569 & 22 & 51 \\
\hline siraf_060 & vessel & naturally aqua & Main group (A) & 67.7 & 12.7 & 2.45 & 2.46 & 1.14 & 9.10 & 1.42 & 1.39 & 0.30 & 0.60 & 18 & 106 & 1695 & 17 & 75 \\
\hline siraf_054 & vessel & light green & Main group (A) & 66.3 & 13.5 & 2.96 & 2.27 & 1.71 & 9.39 & 0.93 & 1.56 & 0.33 & 0.38 & 16 & 99 & 1896 & 22 & 84 \\
\hline siraf_034 & vessel & light green & Main group (A) & 65.8 & 13.7 & 2.98 & 2.26 & 1.71 & 9.55 & 0.84 & 1.60 & 0.31 & 0.58 & 17 & 99 & 1847 & 21 & 76 \\
\hline siraf_064 & vessel & light green & Main group (A) & 65.5 & 13.7 & 2.95 & 2.25 & 1.69 & 9.65 & 0.86 & 1.73 & 0.31 & 0.67 & 17 & 100 & 1848 & 21 & 94 \\
\hline siraf_070 & vessel & light green & Main group (A) & 63.3 & 15.0 & 3.03 & 2.51 & 1.46 & 10.92 & 1.57 & 0.74 & 0.38 & 0.34 & 18 & 108 & 1899 & 18 & 111 \\
\hline siraf_043 & chunk? & green & Main group (A) & 64.7 & 13.3 & 2.80 & 2.45 & 1.64 & 10.40 & 0.94 & 2.12 & 0.33 & 0.62 & 17 & 115 & 1831 & 21 & 93 \\
\hline siraf_068 & vessel & light green & Main group (A) & 65.9 & 13.2 & 2.87 & 2.18 & 1.48 & 9.81 & 1.80 & 0.93 & 0.35 & 0.65 & 15 & 122 & 1988 & 21 & 146 \\
\hline siraf_026 & vessel & light blue & Main group (A) & 68.0 & 12.3 & 2.46 & 2.03 & 1.32 & 8.94 & 2.45 & 0.46 & 0.32 & 0.63 & 13 & 98 & 1992 & 19 & 117 \\
\hline siraf_051 & vessel & dark blue & Main group (A) & 66.6 & 12.5 & 2.83 & 2.22 & 1.16 & 8.33 & 2.13 & 2.28 & 0.30 & 0.56 & 19 & 87 & 1992 & 18 & 86 \\
\hline siraf_069 & vessel & light green & Main group (A) & 67.7 & 14.0 & 1.77 & 2.49 & 1.02 & 8.14 & 0.60 & 2.43 & 0.26 & 0.96 & 15 & 110 & 1682 & 54 & 44 \\
\hline siraf_056 & vessel & light green & Main group (A) & 68.4 & 12.8 & 2.68 & 1.82 & 1.25 & 8.66 & 1.06 & 1.75 & 0.31 & 0.68 & 16 & 88 & 1770 & 18 & 63 \\
\hline siraf_047 & vessel rim & light green & Main group (A) & 69.0 & 13.1 & 3.27 & 1.74 & 1.03 & 8.17 & 1.70 & 0.33 & 0.31 & 0.51 & 15 & 89 & 2037 & 17 & 82 \\
\hline siraf_065 & vessel & light green & Main group (B) & 69.3 & 14.8 & 1.69 & 2.57 & 0.79 & 7.38 & 0.50 & 1.62 & 0.19 & 0.80 & 25 & 139 & 758 & 8 & 21 \\
\hline siraf_028 & vessel & colourless & Main group (B) & 66.1 & 14.8 & 2.11 & 3.01 & 0.95 & 9.17 & 0.61 & 1.83 & 0.20 & 0.76 & 25 & 104 & 956 & 11 & 31 \\
\hline siraf_020 & vessel & naturally aqua & Main group (B) & 70.1 & 12.1 & 2.60 & 2.57 & 1.04 & 9.01 & 0.76 & 0.44 & 0.31 & 0.60 & 19 & 114 & 987 & 11 & 53 \\
\hline siraf_025 & handle & yellow-brown & Main group (B) & 68.0 & 12.6 & 2.68 & 3.08 & 1.35 & 8.09 & 0.68 & 2.29 & 0.24 & 0.57 & 17 & 95 & 1044 & 15 & 51 \\
\hline siraf_066 & vessel & light green & Main group (B) & 70.0 & 13.4 & 2.33 & 2.15 & 1.49 & 6.50 & 1.69 & 0.93 & 0.20 & 0.72 & 24 & 89 & 1085 & 18 & 33 \\
\hline siraf_007 & waste glass & yellow-green & Main group (B) & 69.8 & 13.7 & 1.83 & 2.41 & 0.64 & 6.59 & 0.93 & 2.72 & 0.19 & 0.71 & 22 & 123 & 909 & 9 & 27 \\
\hline siraf_050 & vessel & light green & Main group (B) & 67.9 & 14.0 & 2.03 & 2.81 & 0.84 & 7.85 & 1.66 & 1.45 & 0.22 & 0.68 & 21 & 111 & 1025 & 11 & 24 \\
\hline siraf_044 & chunk? & $\begin{array}{l}\text { colourless- } \\
\text { light green? }\end{array}$ & Main group (B) & 69.6 & 14.5 & 1.98 & 2.58 & 0.69 & 6.56 & 0.43 & 2.26 & 0.21 & 0.80 & 26 & 132 & 1023 & 9 & 25 \\
\hline siraf_058 & vessel & naturally aqua & Main group (B) & 69.9 & 14.1 & 1.98 & 2.55 & 0.68 & 6.69 & 0.43 & 2.27 & 0.20 & 0.78 & 26 & 125 & 1057 & 10 & 19 \\
\hline siraf_049 & vessel & colourless & Main group (B) & 71.9 & 14.2 & 1.72 & 2.31 & 0.64 & 4.93 & 0.34 & 2.55 & 0.20 & 0.82 & 22 & 220 & 1000 & 9 & 24 \\
\hline
\end{tabular}




\begin{tabular}{|c|c|c|c|c|c|c|c|c|c|c|c|c|c|c|c|c|c|c|}
\hline siraf_096 & indeterminate & naturally aqua & Main group (B) & 70.7 & 12.5 & 2.06 & 2.71 & 1.32 & 6.95 & 0.74 & 1.21 & 0.35 & 0.91 & 16 & 143 & 1907 & 20 & 40 \\
\hline siraf_021 & vessel & $\begin{array}{l}\text { aqua-light } \\
\text { green }\end{array}$ & Main group (B) & 67.7 & 14.6 & 2.34 & 2.29 & 0.83 & 9.34 & 0.45 & 1.03 & 0.24 & 0.71 & 21 & 101 & 1572 & 15 & 32 \\
\hline siraf_015 & $\begin{array}{l}\text { working } \\
\text { debris? }\end{array}$ & naturally aqua & Main group (B) & 68.3 & 13.3 & 2.31 & 3.09 & 1.27 & 8.00 & 0.91 & 1.53 & 0.21 & 0.60 & 20 & 102 & 1105 & 14 & 33 \\
\hline siraf_057 & vessel & light green & Main group (B) & 68.0 & 13.2 & 2.19 & 2.06 & 1.28 & 9.39 & 1.71 & 0.54 & 0.22 & 0.72 & 16 & 79 & 1460 & 18 & 33 \\
\hline siraf_031 & vessel & naturally aqua & Main group (B) & 67.7 & 13.1 & 2.49 & 3.18 & 1.26 & 8.39 & 0.86 & 1.69 & 0.22 & 0.57 & 21 & 99 & 1123 & 13 & 42 \\
\hline siraf_091 & vessel & blue & Low $\mathrm{Zr}$ & 66.8 & 14.2 & 3.23 & 4.83 & 1.20 & 6.81 & 0.45 & 0.47 & 0.19 & 0.90 & 23 & 133 & 346 & 10 & 26 \\
\hline siraf_029 & vessel & colourless & Low $\mathrm{Zr}$ & 72.1 & 11.8 & 2.10 & 4.75 & 1.29 & 6.69 & 0.34 & 0.26 & 0.06 & 0.52 & 21 & 58 & 282 & 8 & 15 \\
\hline siraf_098 & vessel & naturally aqua & Low $\mathrm{Zr}$ & 72.7 & 11.3 & 2.42 & 4.51 & 1.06 & 6.38 & 0.37 & 0.39 & 0.10 & 0.56 & 20 & 61 & 280 & 7 & 18 \\
\hline siraf_019 & vessel & $\begin{array}{l}\text { aqua-light } \\
\text { blue }\end{array}$ & Low $\mathrm{Zr}$ & 70.4 & 12.0 & 2.24 & 5.05 & 1.43 & 6.85 & 0.51 & 0.63 & 0.11 & 0.59 & 23 & 76 & 338 & 10 & 28 \\
\hline siraf_023 & vessel & colourless & Low $\mathrm{Zr}$ & 71.3 & 11.7 & 3.09 & 3.30 & 1.83 & 6.89 & 0.62 & 0.30 & 0.20 & 0.59 & 8 & 70 & 485 & 13 & 51 \\
\hline siraf_087 & vessel & $\begin{array}{l}\text { colourless- } \\
\text { light yellow }\end{array}$ & Low $\mathrm{Zr}$ & 67.8 & 13.9 & 3.34 & 3.78 & 2.21 & 6.65 & 0.34 & 1.02 & 0.16 & 0.45 & 16 & 224 & 408 & 9 & 36 \\
\hline siraf_100 & vessel & $\begin{array}{l}\text { colourless- } \\
\text { light green }\end{array}$ & Low $\mathrm{Zr}$ & 68.2 & 13.8 & 3.37 & 3.64 & 2.15 & 6.58 & 0.33 & 0.99 & 0.15 & 0.46 & 15 & 219 & 406 & 9 & 39 \\
\hline siraf_097 & vessel & $\begin{array}{l}\text { colourless- } \\
\text { light green? }\end{array}$ & Low $\mathrm{Zr}$ & 70.2 & 12.8 & 2.31 & 4.88 & 1.20 & 6.75 & 0.39 & 0.47 & 0.12 & 0.65 & 21 & 71 & 406 & 7 & 24 \\
\hline siraf_080 & vessel, rim? & naturally aqua & Low $\mathrm{Zr}$ & 69.2 & 14.0 & 3.16 & 3.86 & 2.73 & 4.71 & 0.43 & 0.90 & 0.12 & 0.57 & 14 & 92 & 481 & 12 & 31 \\
\hline siraf_099 & $\begin{array}{l}\text { vessel rim } \\
\text { (bowl) }\end{array}$ & colourless & Low $\mathrm{Zr}$ & 70.9 & 12.3 & 2.97 & 3.40 & 2.38 & 5.46 & 0.48 & 1.02 & 0.20 & 0.64 & 14 & 138 & 496 & 12 & 41 \\
\hline siraf_092 & vessel & green? & Low $\mathrm{Zr}$ & 65.2 & 15.5 & 3.20 & 4.65 & 2.45 & 6.40 & 0.51 & 0.84 & 0.19 & 0.75 & 14 & 118 & 511 & 21 & 39 \\
\hline siraf_088 & vessel & $\begin{array}{l}\text { colourless- } \\
\text { light yellow }\end{array}$ & Low $\mathrm{Zr}$ & 67.9 & 14.5 & 2.86 & 4.21 & 2.65 & 5.55 & 0.45 & 0.96 & 0.14 & 0.56 & 16 & 83 & 558 & 11 & 23 \\
\hline siraf_083 & vessel & light green & Low $\mathrm{Zr}$ & 68.0 & 14.3 & 2.85 & 4.22 & 2.68 & 5.49 & 0.45 & 1.00 & 0.14 & 0.56 & 16 & 82 & 559 & 11 & 23 \\
\hline siraf_030 & vessel & colourless & Low $\mathrm{Zr}$ & 65.1 & 15.2 & 3.24 & 3.19 & 2.62 & 7.24 & 0.77 & 1.36 & 0.21 & 0.72 & 14 & 96 & 723 & 17 & 46 \\
\hline siraf_046 & vessel & colourless & Low $\mathrm{Zr}$ & 65.5 & 15.0 & 3.28 & 3.14 & 2.55 & 7.14 & 0.77 & 1.35 & 0.23 & 0.73 & 14 & 96 & 729 & 17 & 50 \\
\hline siraf_048 & vessel & colourless & Low $\mathrm{Zr}$ & 65.7 & 14.8 & 3.26 & 3.15 & 2.56 & 7.16 & 0.76 & 1.35 & 0.23 & 0.71 & 13 & 92 & 738 & 17 & 46 \\
\hline siraf_008 & vessel base & $\begin{array}{l}\text { yellowish- } \\
\text { colourless }\end{array}$ & Low $\mathrm{Zr}$ & 67.1 & 13.4 & 3.22 & 3.14 & 3.25 & 7.03 & 0.71 & 1.04 & 0.20 & 0.57 & 14 & 92 & 743 & 17 & 55 \\
\hline siraf_009 & vial neck & dark blue & Low $\mathrm{Zr}$ & 69.3 & 12.8 & 2.18 & 2.37 & 2.12 & 5.62 & 2.84 & 0.50 & 0.21 & 0.54 & 38 & 160 & 817 & 18 & 52 \\
\hline siraf_033 & vessel & $\begin{array}{l}\text { black (very } \\
\text { dark blue) }\end{array}$ & Low $\mathrm{Zr}$ & 67.7 & 13.1 & 1.71 & 2.39 & 1.79 & 5.92 & 3.17 & 1.54 & 0.24 & 0.78 & 23 & 136 & 737 & 22 & 58 \\
\hline siraf_089 & indeterminate & dark blue & Low $\mathrm{Zr}$ & 64.0 & 14.3 & 2.55 & 3.99 & 2.55 & 7.72 & 1.26 & 1.61 & 0.32 & 0.69 & 16 & 126 & 926 & 22 & 65 \\
\hline siraf_081 & vessel & indeterminate & Low $\mathrm{Zr}$ & 67.0 & 14.0 & 3.10 & 3.93 & 2.67 & 5.77 & 0.71 & 1.49 & 0.19 & 0.60 & 15 & 108 & 1223 & 16 & 43 \\
\hline siraf_101 & vessel & light green & Low $\mathrm{Zr}$ & 66.5 & 14.2 & 2.92 & 3.27 & 2.29 & 6.62 & 0.78 & 2.05 & 0.30 & 0.66 & 15 & 92 & 922 & 23 & 65 \\
\hline siraf_067 & vessel & naturally aqua & Low $\mathrm{Zr}$ & 65.6 & 14.9 & 2.84 & 4.11 & 2.04 & 6.72 & 0.71 & 1.84 & 0.25 & 0.59 & 19 & 96 & 744 & 20 & 60 \\
\hline
\end{tabular}




\begin{tabular}{|c|c|c|c|c|c|c|c|c|c|c|c|c|c|c|c|c|c|c|}
\hline siraf_082 & vessel & indeterminate & Low $\mathrm{Zr}$ & 66.0 & 14.3 & 2.94 & 3.35 & 2.28 & 6.76 & 0.77 & 2.19 & 0.29 & 0.66 & 15 & 95 & 912 & 23 & 60 \\
\hline & & & & & & & & & & & & & & & & & & \\
\hline siraf_093_y & $\begin{array}{l}\text { bangle (twisted } \\
\text { with threads) }\end{array}$ & yellow & Low-Mn & 52.4 & 18.3 & 2.66 & 3.58 & 1.52 & 5.43 & 0.77 & 0.04 & 0.30 & 0.86 & 8 & 128 & 491 & 13 & 23 \\
\hline siraf_076 & $\begin{array}{l}\text { bangle } \\
\text { (twisted) }\end{array}$ & blue & Low-Mn & 68.5 & 17.0 & 2.87 & 2.40 & 0.82 & 5.50 & 0.76 & 0.18 & 0.29 & 0.71 & 14 & 94 & 311 & 8 & 20 \\
\hline siraf_093_b & $\begin{array}{l}\text { bangle (twisted } \\
\text { with threads) }\end{array}$ & blue & Low-Mn & 64.0 & 19.2 & 2.78 & 3.78 & 1.62 & 5.36 & 1.33 & 0.05 & 0.29 & 0.89 & 7 & 133 & 528 & 13 & 41 \\
\hline siraf_079 & bangle & $\begin{array}{l}\text { indeterminate } \\
\text { (blue?) }\end{array}$ & Low-Mn & 63.3 & 15.5 & 3.93 & 4.03 & 2.14 & 8.58 & 0.91 & 0.07 & 0.28 & 0.90 & 8 & 140 & 774 & 17 & 60 \\
\hline siraf_078 & $\begin{array}{l}\text { bangle (twisted } \\
\text { with threads) }\end{array}$ & blue & Low-Mn & 64.2 & 17.0 & 3.61 & 3.21 & 1.66 & 6.85 & 1.56 & 0.06 & 0.39 & 0.89 & 12 & 126 & 867 & 14 & 20 \\
\hline siraf_077 & $\begin{array}{l}\text { bangle } \\
\text { (twisted?) }\end{array}$ & $\begin{array}{l}\text { light blue- } \\
\text { turquoise }\end{array}$ & Low-Mn & 66.4 & 19.4 & 3.62 & 2.14 & 0.53 & 4.33 & 0.31 & 0.03 & 0.36 & 0.97 & 18 & 106 & 1923 & 20 & 33 \\
\hline siraf_095 & $\begin{array}{l}\begin{array}{l}\text { bangle } \\
\text { (twisted) }\end{array} \\
\end{array}$ & $\begin{array}{l}\text { indeterminate } \\
\text { (blue?) }\end{array}$ & Low-Mn & 72.0 & 13.1 & 3.28 & 1.92 & 0.51 & 5.21 & 1.95 & 0.02 & 0.26 & 0.76 & 22 & 107 & 3114 & 16 & 39 \\
\hline siraf_090 & kohl stick & light green & $\begin{array}{l}\text { High-Al, Low- } \\
\text { Mn (v-Na-Al) }\end{array}$ & 56.8 & 14.2 & 7.92 & 2.89 & 7.58 & 7.15 & 1.83 & 0.03 & 0.34 & 0.49 & 21 & 111 & 1894 & 32 & 25 \\
\hline siraf_094 & $\begin{array}{l}\text { bangle } \\
\text { (twisted) }\end{array}$ & $\begin{array}{l}\text { indeterminate } \\
\text { (light green?) }\end{array}$ & $\begin{array}{l}\text { High-Al, Low- } \\
\text { Mn (v-Na-Al) }\end{array}$ & 57.8 & 12.2 & 7.17 & 2.74 & 8.06 & 8.28 & 2.00 & 0.03 & 0.37 & 0.59 & 24 & 88 & 2102 & 38 & 33 \\
\hline siraf_075 & bangle & dark aqua & $\begin{array}{l}\text { High-Al, Low- } \\
\text { Mn (m-Na-Al) }\end{array}$ & 64.1 & 20.5 & 0.76 & 1.52 & 4.73 & 2.84 & 1.42 & 0.06 & 0.10 & 1.43 & 14 & 332 & 2828 & 60 & 38 \\
\hline siraf_006 & vessel & naturally aqua & outlier & 67.3 & 14.3 & 2.03 & 3.22 & 2.17 & 8.44 & 0.86 & 0.04 & 0.38 & 0.90 & 10 & 135 & 650 & 15 & 66 \\
\hline siraf_035 & vessel & light green & outlier & 63.5 & 15.5 & 3.30 & 4.90 & 3.23 & 7.11 & 1.06 & 0.04 & 0.31 & 0.73 & 12 & 138 & 816 & 21 & 63 \\
\hline siraf_022 & vessel & $\begin{array}{l}\text { aqua-light } \\
\text { green }\end{array}$ & outlier & 61.6 & 16.4 & 2.88 & 4.72 & 3.63 & 8.46 & 0.86 & 0.04 & 0.22 & 0.80 & 13 & 143 & 1009 & 19 & 199 \\
\hline siraf_086 & vessel base & light green & outlier & 67.3 & 14.9 & 3.12 & 2.10 & 0.87 & 5.80 & 3.65 & 0.04 & 0.32 & 0.71 & 16 & 113 & 3065 & 50 & 50 \\
\hline
\end{tabular}




\begin{tabular}{|c|c|c|c|c|c|c|c|c|c|c|c|c|c|c|c|c|c|c|c|c|c|c|}
\hline Sample ID & Object & Colour & $\begin{array}{l}\text { Glass } \\
\text { group }\end{array}$ & Co & $\mathbf{N i}$ & $\mathbf{C u}$ & $\mathbf{Z n}$ & As & $\mathbf{R b}$ & $\mathbf{S r}$ & $\mathbf{Y}$ & $\mathbf{Z r}$ & In & Sn & $\mathbf{S b}$ & $\mathbf{B a}$ & La & $\mathrm{Ce}$ & Nd & $\mathbf{P b}$ & Th & $\mathbf{U}$ \\
\hline siraf_004 & $\begin{array}{l}\text { vessel } \\
\text { base }\end{array}$ & $\begin{array}{l}\text { light } \\
\text { green- } \\
\text { colourless }\end{array}$ & $\begin{array}{l}\text { Main } \\
\text { group (A) }\end{array}$ & 15 & 27 & 39 & 27 & 1 & 10 & 468 & 4 & 272 & 0 & 1 & 0 & 208 & 2 & 4 & 2 & 1 & 1 & 1 \\
\hline siraf_053 & $\begin{array}{l}\text { vessel } \\
\text { base }\end{array}$ & $\begin{array}{l}\text { naturally } \\
\text { aqua }\end{array}$ & $\begin{array}{l}\text { Main } \\
\text { group (A) }\end{array}$ & 4 & 12 & 10 & 35 & 17 & 8 & 901 & 6 & 277 & 0 & 2 & 2 & $\begin{array}{r}226 \\
8\end{array}$ & 26 & 24 & 5 & 0 & 1 & 1 \\
\hline siraf_005 & vessel & $\begin{array}{l}\text { naturally } \\
\text { aqua }\end{array}$ & $\begin{array}{l}\text { Main } \\
\text { group (A) }\end{array}$ & 7 & 13 & 22 & 31 & 1 & 8 & 751 & 5 & 340 & 0 & 1 & 0 & 184 & 3 & 6 & 3 & 0 & 1 & 1 \\
\hline siraf_055 & vessel & light green & $\begin{array}{l}\text { Main } \\
\text { group (A) }\end{array}$ & 7 & 16 & 19 & 42 & 2 & 9 & 729 & 6 & 352 & 0 & 1 & 0 & 104 & 5 & 9 & 4 & 4 & 2 & 1 \\
\hline siraf_045 & vessel & light green & $\begin{array}{l}\text { Main } \\
\text { group (A) }\end{array}$ & 6 & 21 & 19 & 36 & 2 & 6 & 687 & 7 & 366 & 0 & 1 & 0 & 289 & 4 & 7 & 3 & 0 & 1 & 1 \\
\hline siraf_062 & vessel & $\begin{array}{l}\text { naturally } \\
\text { aqua }\end{array}$ & $\begin{array}{l}\text { Main } \\
\text { group (A) }\end{array}$ & 54 & 29 & 133 & 49 & 3 & 8 & 654 & 6 & 387 & 0 & 8 & 0 & 119 & 4 & 8 & 4 & 31 & 1 & 1 \\
\hline siraf_052 & vessel & $\begin{array}{l}\text { yellow- } \\
\text { green }\end{array}$ & $\begin{array}{l}\text { Main } \\
\text { group (A) }\end{array}$ & 4 & 23 & 10 & 37 & 2 & 7 & 859 & 7 & 388 & 0 & 1 & 0 & 166 & 5 & 9 & 4 & 0 & 1 & 1 \\
\hline siraf_084 & vessel rim & $\begin{array}{l}\text { naturally } \\
\text { aqua }\end{array}$ & $\begin{array}{l}\text { Main } \\
\text { group (A) }\end{array}$ & 4 & 11 & 20 & 34 & 4 & 7 & 673 & 6 & 391 & 0 & 1 & 0 & 163 & 7 & 10 & 4 & 4 & 1 & 1 \\
\hline siraf_059 & vessel & $\begin{array}{l}\text { naturally } \\
\text { aqua }\end{array}$ & $\begin{array}{l}\text { Main } \\
\text { group (A) }\end{array}$ & 42 & 22 & 183 & 93 & 6 & 8 & 804 & 7 & 400 & 0 & 9 & 1 & 435 & 5 & 8 & 4 & 221 & 1 & 1 \\
\hline siraf_032 & vessel rim & light green & $\begin{array}{l}\text { Main } \\
\text { group (A) }\end{array}$ & 10 & 15 & 54 & 41 & 2 & 11 & 1321 & 7 & 409 & 0 & 1 & 0 & 167 & 6 & 11 & 5 & 9 & 2 & 1 \\
\hline siraf_074 & unknown & green & $\begin{array}{l}\text { Main } \\
\text { group (A) }\end{array}$ & 10 & 27 & 60 & 48 & 3 & 5 & 615 & 7 & 427 & 0 & 0 & 0 & 194 & 4 & 8 & 4 & 0 & 1 & 1 \\
\hline siraf_042 & chunk? & $\begin{array}{l}\text { light } \\
\text { green-aqua }\end{array}$ & $\begin{array}{l}\text { Main } \\
\text { group (A) }\end{array}$ & 6 & 25 & 70 & 48 & 1 & 6 & 629 & 7 & 429 & 0 & 0 & 0 & 184 & 5 & 9 & 4 & 0 & 1 & 1 \\
\hline siraf_073 & unknown & green & $\begin{array}{l}\text { Main } \\
\text { group (A) }\end{array}$ & 7 & 23 & 20 & 58 & 2 & 8 & 669 & 7 & 435 & 0 & 0 & 0 & 171 & 4 & 9 & 4 & 0 & 2 & 1 \\
\hline siraf_038 & chunk? & green & $\begin{array}{l}\text { Main } \\
\text { group (A) }\end{array}$ & 10 & 25 & 110 & 46 & 2 & 5 & 608 & 7 & 439 & 0 & 1 & 0 & 198 & 4 & 8 & 3 & 0 & 1 & 1 \\
\hline siraf_037 & chunk? & $\begin{array}{l}\text { light } \\
\text { green-aqua }\end{array}$ & $\begin{array}{l}\text { Main } \\
\text { group (A) }\end{array}$ & 8 & 24 & 42 & 47 & 2 & 5 & 620 & 7 & 445 & 0 & 1 & 0 & 194 & 4 & 8 & 4 & 0 & 1 & 1 \\
\hline siraf_039 & chunk? & green & $\begin{array}{l}\text { Main } \\
\text { group (A) }\end{array}$ & 9 & 24 & 78 & 46 & 2 & 5 & 604 & 7 & 450 & 0 & 1 & 0 & 190 & 4 & 8 & 4 & 7 & 1 & 1 \\
\hline siraf_071 & unknown & light green & $\begin{array}{l}\text { Main } \\
\text { group (A) }\end{array}$ & 5 & 21 & 47 & 44 & 2 & 5 & 580 & 7 & 456 & 0 & 1 & 0 & 196 & 4 & 7 & 3 & 0 & 1 & 1 \\
\hline siraf_072 & unknown & light green & $\begin{array}{l}\text { Main } \\
\text { group (A) }\end{array}$ & 4 & 18 & 23 & 43 & 2 & 5 & 581 & 7 & 459 & 0 & 1 & 0 & 155 & 4 & 7 & 3 & 0 & 1 & 1 \\
\hline
\end{tabular}




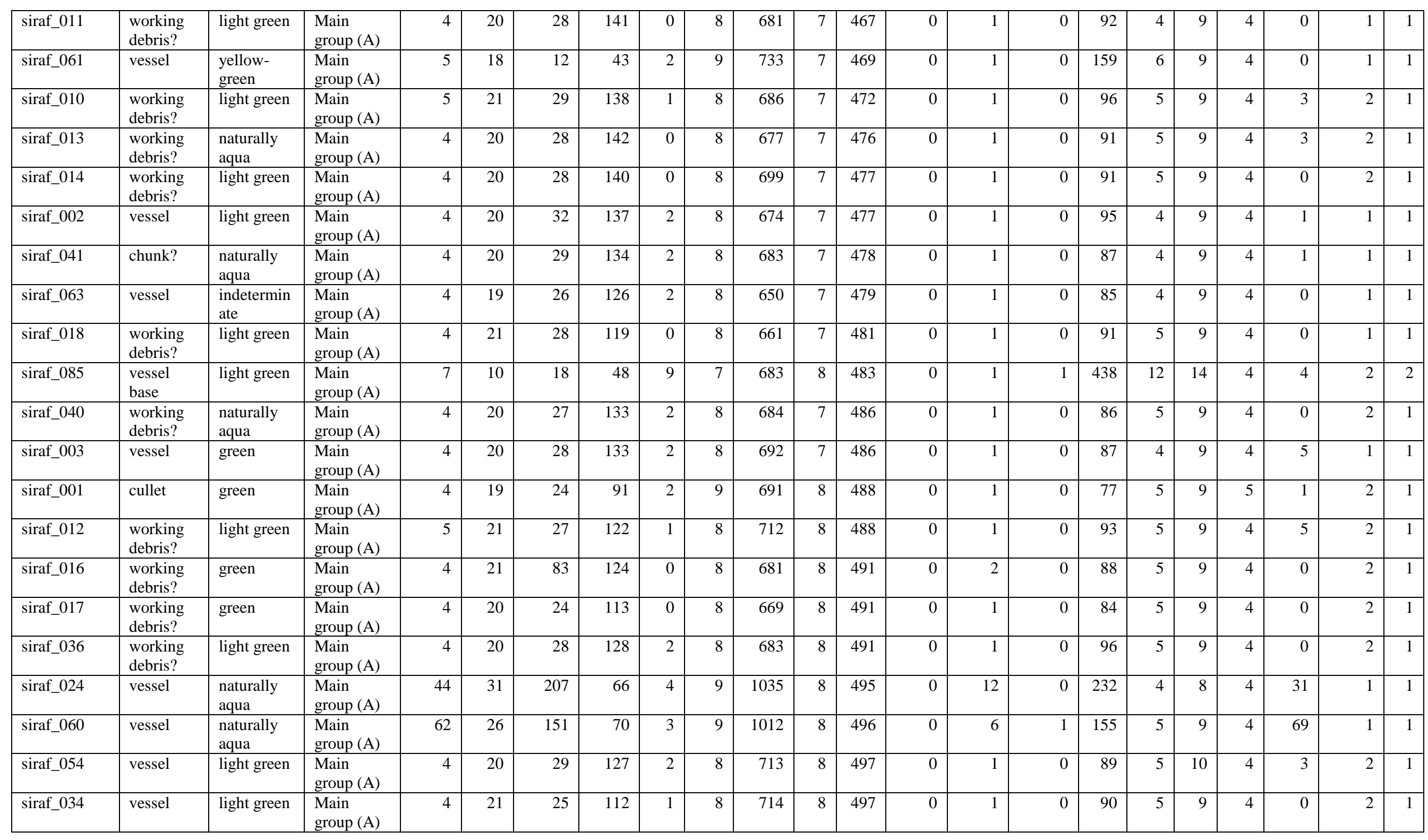




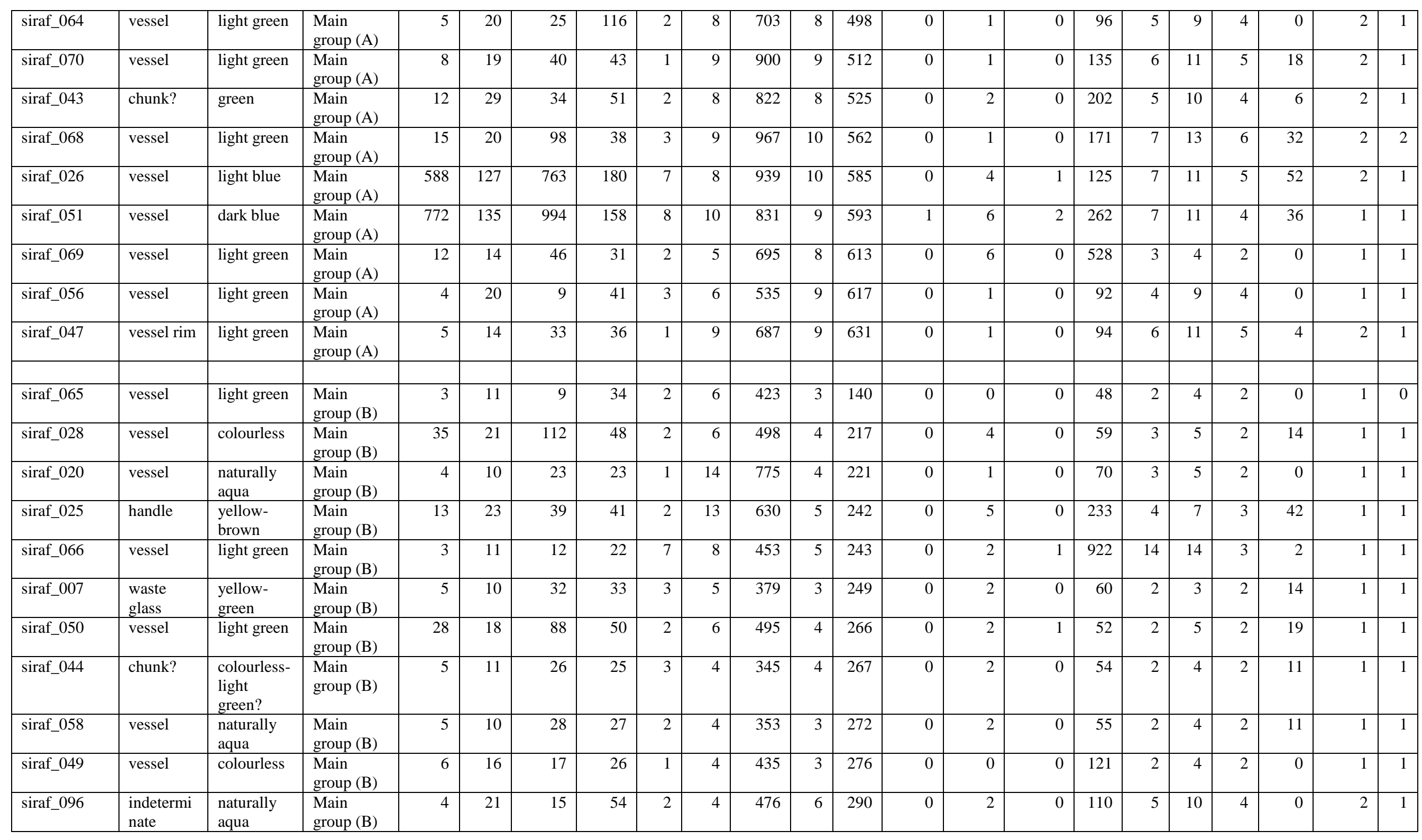




\begin{tabular}{|c|c|c|c|c|c|c|c|c|c|c|c|c|c|c|c|c|c|c|c|c|c|c|}
\hline siraf_021 & vessel & $\begin{array}{l}\text { aqua-light } \\
\text { green }\end{array}$ & $\begin{array}{l}\text { Main } \\
\text { group (B) }\end{array}$ & 3 & 12 & 9 & 27 & 1 & 6 & 587 & 5 & 294 & 0 & 1 & 0 & 115 & 3 & 6 & 3 & 0 & 1 & 1 \\
\hline siraf_015 & $\begin{array}{l}\text { working } \\
\text { debris? }\end{array}$ & $\begin{array}{l}\text { naturally } \\
\text { aqua }\end{array}$ & $\begin{array}{l}\text { Main } \\
\text { group (B) }\end{array}$ & 85 & 39 & 315 & 102 & 2 & 10 & 567 & 6 & 296 & 0 & 9 & 0 & 106 & 4 & 7 & 4 & 82 & 1 & 1 \\
\hline siraf_057 & vessel & light green & $\begin{array}{l}\text { Main } \\
\text { group (B) }\end{array}$ & 4 & 13 & 14 & 33 & 12 & 6 & 740 & 5 & 300 & 0 & 1 & 1 & 386 & 16 & 18 & 4 & 0 & 1 & 1 \\
\hline siraf_031 & vessel & $\begin{array}{l}\text { naturally } \\
\text { aqua }\end{array}$ & $\begin{array}{l}\text { Main } \\
\text { group (B) }\end{array}$ & 68 & 33 & 228 & 77 & 3 & 11 & 636 & 6 & 319 & 0 & 10 & 0 & 103 & 4 & 7 & 3 & 51 & 1 & 1 \\
\hline siraf_091 & vessel & blue & Low Zr & 4 & 18 & 5120 & 124 & 25 & 17 & 503 & 3 & 16 & 0 & 28 & 9 & 129 & 3 & 5 & 2 & 72 & 1 & 0 \\
\hline siraf_098 & vessel & $\begin{array}{l}\text { naturally } \\
\text { aqua }\end{array}$ & Low $\mathrm{Zr}$ & 16 & 16 & 85 & 26 & 2 & 14 & 352 & 3 & 34 & 0 & 1 & 0 & 119 & 3 & 6 & 3 & 13 & 1 & 0 \\
\hline siraf_019 & vessel & $\begin{array}{l}\text { aqua-light } \\
\text { blue }\end{array}$ & Low $\mathrm{Zr}$ & 43 & 29 & 157 & 41 & 3 & 15 & 366 & 3 & 38 & 0 & 5 & 0 & 130 & 3 & 6 & 3 & 79 & 1 & 1 \\
\hline siraf_023 & vessel & colourless & Low $\mathrm{Zr}$ & 3 & 23 & 12 & 20 & 1 & 14 & 210 & 3 & 42 & 0 & 0 & 0 & 112 & 4 & 7 & 3 & 0 & 1 & 0 \\
\hline siraf_087 & vessel & $\begin{array}{l}\text { colourless- } \\
\text { light } \\
\text { yellow }\end{array}$ & Low $\mathrm{Zr}$ & 5 & 10 & 9 & 20 & 2 & 17 & 594 & 4 & 52 & 0 & 0 & 0 & 242 & 5 & 9 & 4 & 0 & 1 & 0 \\
\hline siraf_100 & vessel & $\begin{array}{l}\text { colourless- } \\
\text { light green }\end{array}$ & Low $\mathrm{Zr}$ & 5 & 9 & 9 & 20 & 2 & 17 & 600 & 4 & 53 & 0 & 0 & 0 & 239 & 5 & 10 & 4 & 0 & 1 & 0 \\
\hline siraf_097 & vessel & $\begin{array}{l}\text { colourless- } \\
\text { light } \\
\text { green? }\end{array}$ & Low $\mathrm{Zr}$ & 1 & 13 & 7 & 15 & 2 & 13 & 344 & 3 & 55 & 0 & 0 & 0 & 78 & 3 & 6 & 3 & 0 & 1 & 0 \\
\hline siraf_080 & $\begin{array}{l}\text { vessel, } \\
\text { rim? }\end{array}$ & $\begin{array}{l}\text { naturally } \\
\text { aqua }\end{array}$ & Low Zr & 3 & 14 & 10 & 21 & 3 & 22 & 402 & 4 & 56 & 0 & 0 & 0 & 238 & 5 & 10 & 5 & 0 & 1 & 1 \\
\hline siraf_099 & $\begin{array}{l}\text { vessel rim } \\
\text { (bowl) }\end{array}$ & colourless & Low $\mathrm{Zr}$ & 5 & 14 & 13 & 26 & 2 & 18 & 460 & 4 & 62 & 0 & 1 & 0 & 246 & 6 & 11 & 5 & 3 & 1 & 1 \\
\hline siraf_092 & vessel & green? & Low $\mathrm{Zr}$ & 5 & 12 & 144 & 30 & 5 & 19 & 605 & 4 & 62 & 0 & 10 & 0 & 216 & 6 & 11 & 5 & 34 & 1 & 1 \\
\hline siraf_088 & vessel & $\begin{array}{l}\text { colourless- } \\
\text { light } \\
\text { yellow }\end{array}$ & Low $\mathrm{Zr}$ & 2 & 14 & 7 & 24 & 14 & 20 & 454 & 4 & 63 & 0 & 0 & 0 & 224 & 5 & 10 & 5 & 1 & 1 & 1 \\
\hline siraf_083 & vessel & light green & Low $\mathrm{Zr}$ & 3 & 14 & 7 & 25 & 14 & 20 & 452 & 4 & 64 & 0 & 0 & 1 & 229 & 5 & 10 & 5 & 1 & 1 & 1 \\
\hline siraf_030 & vessel & colourless & Low Zr & 6 & 16 & 32 & 38 & 2 & 19 & 336 & 5 & 66 & 0 & 0 & 0 & 457 & 6 & 11 & 6 & 0 & 1 & 1 \\
\hline siraf_046 & vessel & colourless & Low $\mathrm{Zr}$ & 6 & 16 & 33 & 40 & 2 & 19 & 329 & 5 & 66 & 0 & 1 & 0 & 448 & 6 & 11 & 6 & 0 & 1 & 1 \\
\hline siraf_048 & vessel & colourless & Low $\mathrm{Zr}$ & 6 & 16 & 32 & 38 & 2 & 19 & 332 & 5 & 67 & 0 & 1 & 0 & 448 & 7 & 12 & 6 & 1 & 1 & 1 \\
\hline siraf_008 & $\begin{array}{l}\text { vessel } \\
\text { base }\end{array}$ & $\begin{array}{l}\text { yellowish- } \\
\text { colourless }\end{array}$ & Low $\mathrm{Zr}$ & 3 & 20 & 18 & 31 & 1 & 25 & 329 & 5 & 75 & 0 & 2 & 0 & 240 & 6 & 11 & 5 & 1 & 2 & 1 \\
\hline siraf_009 & vial neck & dark blue & Low $\mathrm{Zr}$ & 1580 & 368 & 4345 & 461 & 17 & 11 & 374 & 5 & 91 & 1 & 13 & 3 & 153 & 7 & 14 & 6 & 103 & 2 & 1 \\
\hline
\end{tabular}




\begin{tabular}{|c|c|c|c|c|c|c|c|c|c|c|c|c|c|c|c|c|c|c|c|c|c|c|}
\hline siraf_033 & vessel & $\begin{array}{l}\text { black (very } \\
\text { dark blue) }\end{array}$ & Low $\mathrm{Zr}$ & 2242 & 293 & 5142 & 579 & 22 & 10 & 292 & 4 & 94 & 2 & 29 & 5 & 115 & 7 & 13 & 6 & 93 & 2 & 1 \\
\hline siraf_089 & $\begin{array}{l}\text { indetermi } \\
\text { nate }\end{array}$ & dark blue & Low $\mathrm{Zr}$ & 767 & 37 & 828 & 2623 & 10 & 11 & 484 & 5 & 97 & 1 & 31 & 2 & 284 & 8 & 16 & 7 & 253 & 2 & 1 \\
\hline siraf_081 & vessel & $\begin{array}{l}\text { indetermin } \\
\text { ate }\end{array}$ & Low $\mathrm{Zr}$ & 7 & 17 & 61 & 42 & 6 & 18 & 453 & 6 & 123 & 0 & 56 & 0 & 305 & 7 & 13 & 7 & 555 & 2 & 1 \\
\hline siraf_101 & vessel & light green & Low $\mathrm{Zr}$ & 17 & 27 & 60 & 80 & 5 & 13 & 410 & 5 & 124 & 0 & 3 & 0 & 253 & 9 & 16 & 7 & 254 & 2 & 1 \\
\hline siraf_067 & vessel & $\begin{array}{l}\text { naturally } \\
\text { aqua }\end{array}$ & Low $\mathrm{Zr}$ & 40 & 24 & 151 & 102 & 5 & 13 & 498 & 5 & 125 & 0 & 9 & 0 & 322 & 7 & 13 & 6 & 294 & 2 & 1 \\
\hline siraf_082 & vessel & $\begin{array}{l}\text { indetermin } \\
\text { ate }\end{array}$ & Low $\mathrm{Zr}$ & 17 & 27 & 52 & 80 & 5 & 13 & 412 & 5 & 127 & 0 & 3 & 0 & 245 & 8 & 16 & 7 & 191 & 2 & 1 \\
\hline siraf_093_y & $\begin{array}{l}\text { bangle } \\
\text { (twisted } \\
\text { with } \\
\text { threads) }\end{array}$ & yellow & Low-Mn & 9 & 45 & 292 & 41 & 102 & 8 & 236 & 2 & 14 & 220 & 220 & 59367 & 182 & 39 & 2 & 4 & 2 & 56873 & 1 \\
\hline siraf_076 & $\begin{array}{l}\text { bangle } \\
\text { (twisted) }\end{array}$ & blue & Low-Mn & 240 & 10 & 109 & 49 & 129 & 12 & 292 & 2 & 15 & 8 & 2316 & 1 & 74 & 3 & 5 & 2 & 2699 & 1 & 0 \\
\hline siraf_093_b & $\begin{array}{l}\text { bangle } \\
\text { (twisted } \\
\text { with } \\
\text { threads) }\end{array}$ & blue & Low-Mn & 215 & 30 & 63 & 52 & 188 & 9 & 240 & 3 & 17 & 4 & 1221 & 4 & 41 & 3 & 5 & 2 & 881 & 1 & 0 \\
\hline siraf_079 & bangle & $\begin{array}{l}\text { indetermin } \\
\text { ate (blue?) }\end{array}$ & Low-Mn & 3 & 26 & 20 & 18 & 2 & 9 & 439 & 4 & 30 & 0 & 0 & 0 & 113 & 4 & 9 & 4 & 0 & 1 & 0 \\
\hline siraf_078 & $\begin{array}{l}\text { bangle } \\
\text { (twisted } \\
\text { with } \\
\text { threads) }\end{array}$ & blue & Low-Mn & 258 & 14 & 51 & 62 & 168 & 14 & 286 & 6 & 140 & 1 & 312 & 2 & 180 & 8 & 16 & 7 & 304 & 2 & 1 \\
\hline siraf_077 & $\begin{array}{l}\text { bangle } \\
\text { (twisted?) }\end{array}$ & $\begin{array}{l}\text { light blue- } \\
\text { turquoise }\end{array}$ & Low-Mn & 1 & 10 & 10364 & 69 & 20 & 7 & 415 & 8 & 589 & 1 & 283 & 13 & 25 & 2 & 4 & 2 & 367 & 1 & 9 \\
\hline siraf_095 & $\begin{array}{l}\text { bangle } \\
\text { (twisted) }\end{array}$ & $\begin{array}{l}\text { indetermin } \\
\text { ate (blue?) }\end{array}$ & Low-Mn & 1 & 6 & 9 & 30 & 1 & 8 & 298 & 11 & 914 & 0 & 1 & 0 & 24 & 10 & 14 & 4 & 0 & 2 & 2 \\
\hline & & & & & & & & & & & & & 0 & & & & & & & & & \\
\hline siraf_090 & kohl stick & light green & $\begin{array}{l}\text { High-Al, } \\
\text { Low-Mn }\end{array}$ & 3 & 12 & 14 & 28 & 2 & 60 & 449 & 12 & 119 & 0 & 1 & 0 & 552 & 18 & 36 & 15 & 1 & 4 & 1 \\
\hline \multirow[t]{2}{*}{ siraf_094 } & $\begin{array}{l}\text { bangle } \\
\text { (twisted) }\end{array}$ & $\begin{array}{l}\text { indetermin } \\
\text { ate (light } \\
\text { green?) }\end{array}$ & $\begin{array}{l}\text { High-Al, } \\
\text { Low-Mn }\end{array}$ & 4 & 17 & 12 & 36 & 3 & 58 & 273 & 14 & 127 & 0 & 1 & 0 & 692 & 20 & 41 & 18 & 0 & 5 & 1 \\
\hline & & & & & & & & & & & & & 0 & & & & & & & & & \\
\hline siraf_075 & bangle & dark aqua & $\begin{array}{l}\text { High-Al, } \\
\text { Low-Mn } \\
\text { (m-Na-Al) }\end{array}$ & 9 & 19 & 13760 & 51 & 38 & 15 & 209 & 11 & 161 & 0 & 27 & 5 & 195 & 18 & 35 & 15 & 56 & 6 & 26 \\
\hline
\end{tabular}




\begin{tabular}{|c|c|c|c|c|c|c|c|c|c|c|c|c|c|c|c|c|c|c|c|c|c|c|}
\hline & & & & & & & & & & & & & 0 & & & & & & & & & \\
\hline siraf_006 & vessel & $\begin{array}{l}\text { naturally } \\
\text { aqua }\end{array}$ & outlier & 4 & 34 & 16 & 30 & 1 & 8 & 311 & 4 & 43 & 0 & 0 & 0 & 98 & 4 & 8 & 4 & 2 & 1 & 1 \\
\hline siraf_035 & vessel & light green & outlier & 5 & 38 & 16 & 28 & 1 & 16 & 408 & 5 & 49 & 0 & 0 & 0 & 110 & 6 & 11 & 5 & 0 & 2 & 1 \\
\hline siraf_022 & vessel & $\begin{array}{l}\text { aqua-light } \\
\text { green }\end{array}$ & outlier & 3 & 24 & 12 & 23 & 1 & 18 & 582 & 5 & 89 & 0 & 0 & 0 & 193 & 6 & 10 & 5 & 0 & 1 & 1 \\
\hline siraf_086 & $\begin{array}{l}\text { vessel } \\
\text { base }\end{array}$ & light green & outlier & 2 & 12 & 16 & 31 & 3 & 9 & 429 & 11 & 995 & 0 & 1 & 0 & 32 & 4 & 7 & 3 & 0 & 2 & 2 \\
\hline
\end{tabular}

